\title{
Multiple $\mathrm{N}$-methylation of MT-II backbone amide bonds leads to melanocortin receptor subtype hMC1R selectivity; pharmacological and conformational studies
}

\author{
Lucas Doedens ${ }^{1, \ddagger}$, Florian Opperer ${ }^{1, \ddagger}$, Minying Cai ${ }^{2, \ddagger}$, Johannes G. Beck ${ }^{1, \ddagger}$, Matt Dedek ${ }^{2}$, \\ Erin Palmer ${ }^{2}$, Victor J. Hruby ${ }^{2, *}$, and Horst Kessler ${ }^{1,{ }^{*}}$ \\ Victor J. Hruby: hruby@email.arizona.edu; Horst Kessler: kessler@ch.tum.de \\ ${ }^{1}$ Institute for Advanced Study and Center for Integrated Protein Science at the Technische \\ Universität München, Lichtenbergstr. 4, 85747 Garching, Germany \\ ${ }^{2}$ Department of Chemistry and Biochemistry, University of Arizona, Tucson, Arizona, 85721, U.S.A
}

\begin{abstract}
Multiple $N$-methylation is a novel technology to improve bioavailability of peptides and increase receptor subtype selectivity. This technique has been applied here to the superpotent but non-selective cyclic peptide MT-II. A library of all possible 31 backbone $N$-methylated derivatives has been synthesized and tested for binding and activation at melanocortin receptor subtypes 1, 3, 4 and 5. It turned out that selectivity is improved with every introduced $N$-methyl group, resulting in several $\mathrm{N}$-methylated selective and potent agonists for the hMC1R. The most potent of these derivatives is $\mathrm{N}$-methylated on four out of five amide bonds in the cyclic structure. Its solution structure indicates a strongly preferred backbone conformation which resembles other a-MSH analogs but possesses much less flexibility and in addition distinct differences in the spatial arrangement of individual amino acid side chains.
\end{abstract}

\section{Introduction}

$\mathrm{N}$-Methylation of peptide bonds is long known ${ }^{1-3}$ and has often been used to modify biological properties of bioactive peptides. ${ }^{4}$ However, it has become evident only recently that multiple $N$-methylation is a novel technology to improve the pharmacological properties of peptides ${ }^{5}$ and in extreme cases even achieve oral bioavailability ${ }^{6}$ such as found for the antibiotic Cyclosporin. ${ }^{7,8}$ Here we present a complete $N$-methylation library of the cyclic analogue of aMSH, Ac-Nle-c[Asp-His-DPhe-Arg-Trp-Lys]- $\mathrm{NH}_{2}$ (MT-II), a biologically important and potent but non-selective agonist for the melanocortin receptor subtype family. ${ }^{9-} 10$ The goal of our present study was to obtain new peptidic compounds with melanocortin receptor activity and improved selectivity, possessing pharmacological properties superior to those of MT-II. Therefore, we exchanged in a systematic manner His, DPhe, Arg, Trp and Lys by their $N^{\alpha_{-}}$ methylated analogs and studied all of the $31\left(2^{5}-1=31\right)$ possible MT-II-derivatives with one or more methylated backbone nitrogens (Figure 1).

The melanocortin receptors are members of the 7 transmembrane (TM) spanning G-protein coupled receptor (GPCR) superfamily. Five melanocortin receptor subtypes (MCR1-5) have

\footnotetext{
*authors to whom correspondence should be addressed at Technische Universität München (HK) and University of Arizona (VJH). \$contributed equally to these studies

Supporting Information Available: Description of the material included. This material is available free of charge via the Internet at http://pubs.acs.org.
} 
been discovered thus far. $8,11^{-} 17$ They all intracellularly mediate their effects by activating pathways that are cyclic adenosine monophosphate (cAMP) dependent. The diverse MCRs are distributed widely in mammalian tissues, and regulate numerous functions in the body including skin and hair coloration, $18^{-} 20$ inflammation 21 and immunomodulation, 22 steroid production and release, ${ }^{23,24}$ cardiovascular functions, ${ }^{25,26}$ energy homeostasis, ${ }^{27}$ feeding behaviour, ${ }^{28-30}$ penile erection and sexual behaviour ${ }^{31-33}$ and many other functions. These very diverse biological activities generally are associated with only 1 or 2 of the melanocortin receptors that are expressed in different parts of the body. Thus the search for highly selective and potent agonist and antagonist analogues is critical.

The natural endogenous agonistic ligands a-melanocyte stimulating hormone (a-MSH, Ac-

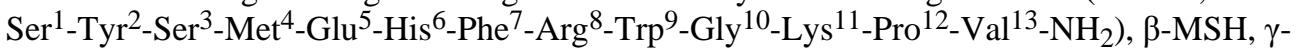
MSH and adrenocorticotropin (ACTH) all are derived from the same precursor protein, proopiomelanocortin (POMC). Structure-function examinations of a-MSH and of a-MSH fragments have lead to the identification of His-Phe-Arg-Trp as the critical pharmacophore for pigmentary activity and other functions of the melanotropin peptides. ${ }^{19}, 20,34-41$ Truncation of the $\alpha$-MSH sequence, keeping amino acids 4-10, exchange of $\mathrm{Met}^{4}$ with Nle, Glu ${ }^{5}$ with Asp, Phe ${ }^{7}$ with DPhe and Gly ${ }^{10}$ with Lys, acetylation of the $\mathrm{Nle}^{4}$ - $\alpha$-nitrogen, amidation of the $C$-terminal carboxyl function, and lactam cyclization resulted in the lactam bridged compound MT-II, a super potent but non-selective agonist at 4 melanocortin receptors MC1R, MC3R, MC4R, MC5R9, 10,41 (not at the MC2R which has ACTH as its ligand, and where a-MSH and its analogues are not active).

A major focus in synthesising new melanotropins is gaining selectivity and improved pharmacological properties that are suitable for medical applications of these compounds. When creating peptidic ligands one possible way to obtain these properties is $N$-methylation of the amide bonds, ${ }^{4-6,42-44}$ since substitution of amide protons with methyl groups can result in receptor subtype selectivity, ${ }^{45-48}$ but also other pharmacological properties can be improved, such as metabolic stability $6,49,51$ lipophilicity, ${ }^{49-51}$ enhanced potency, ${ }^{52-55}$ enhanced bioavailability $6,56,57$ and conformational rigidity. ${ }^{48,51,58}$ It may also turn an agonist into an antagonist. ${ }^{57}$

Application of the $\mathrm{N}$-alkyl scan concept59 to the highly active and selective cyclic pentapeptide cyclo(-RGDfV- $)^{60}$ has led to one of the most active $(0.5 \mathrm{nM})$ and selective inhibitors for the $\alpha_{\mathrm{v}} \beta_{3}$ integrin,55,61 the analog cyclo(-Arg-Gly-Asp-DPhe-(Me)Val-], Cilengitide, ${ }^{55,61}$ which is now in clinical phase III for treatment of glioblastoma. $N$-Alkylation is also present in natural occurring peptides from plants, marine sources and various microorganisms. Several of these compounds exhibit biological activity like antibiotic, ${ }^{62-64}$ antitumor ${ }^{65-67}$ and immunosuppressor activity. ${ }^{6}$

\section{Peptide Design}

Ac-Nle ${ }^{4}-\mathrm{c}\left[\mathrm{Asp}^{5}, \mathrm{DPhe}^{7}, \mathrm{Lys}^{10}\right] \alpha-\mathrm{MSH}(4-10)-\mathrm{NH}_{2}$ (MT-II) was chosen as a template for the design of a combinatorial library to search for more selective melanotropin peptides. Some $\mathrm{N}$-methyl amino acids are commercially available, but most are expensive. However, several methods for synthesizing $\mathrm{N}$-methylated amino acids in solution and on solid supports have been developed. ${ }^{69}$ We decided to do the $N$-methylations on a solid support, which gives flexibility in library design and facilitated coupling, because no coupling of $N$-methylated amino acids to an $N$-methylated peptide is necessary. ${ }^{6}$ We used the procedure originally described by Miller and Scanlan ${ }^{70}$ which has been optimized by Biron et al. and which is compatible with all commonly used amino acids. ${ }^{71}$

A major advantage of the $o$-NBS protecting group coupled to the free amine prior to $\mathrm{N}$ methylation is that deprotection with mercaptoethanol is selective for $N$-methylated derivatives 
and does not occur when the protected amine is not alkylated. ${ }^{71}$ Hence it provides an inherent purification step during synthesis.

Couplings on $N^{\alpha}$-methylamino acids are known to be more challenging than normal couplings.

${ }^{72}$ Hence, these couplings were performed with HATU and HOAt instead of TBTU and HOBt using DIEA as base in NMP yielding in complete couplings after $3 \mathrm{~h}$. Nevertheless, some peptides $(\mathbf{3}, \mathbf{1 3}, \mathbf{2 5})$ could not be purified as sharp peaks by HPLC and were observed as broad peaks or mixtures of two peaks with identical mass, even after repeated synthesis. When the peaks were separated and reinjected, similar chromatograms were observed. This indicated the presence of conformational isomers rather than diastereomers. To study the influence of $N$ methylation on the conformation of the pharmacophore of MT-II, a library of MT-II analogues with single and multiple $N$-methylation in the core sequence of MT-II have been designed and synthesized (Figure 1 and Table 1).

\section{Results and Discussion Biological data}

Competitive binding assays with $\left[{ }^{125} \mathrm{I}\right]-\left[\mathrm{Nle}^{4}, \mathrm{DPhe}{ }^{7}\right]-\alpha-\mathrm{MSH}$ (NDP- $\left.\alpha-\mathrm{MSH}\right)$, and adenylate cyclase assays were performed on HEK293 cells stable expressing the hMC1R, hMC3R, hMC4R, and hMC5R (Table 1 and Table 2, respectively).

In the first group of peptides with the single $N$-methylation screen (peptides 2-6), it is revealed that $N \mathrm{Me}$-DPhe caused a total loss of binding as well as adenylate cyclase activities (Tables 1 and 2) at the hMC1R, hMC3R, hMC4R and hMC5R for peptide 5. For the rest of the core sequence single $N$-methylation does not cause this drastic loss of binding activities (Table 1). The cAMP assay data (Table 2) show that the $N$-methylated peptides $\mathbf{2 , 3}$ and $\mathbf{6}$ still retain full agonist or partial agonist activity toward all subtypes of melanocortin receptors. This phenomenon parallels earlier studies that have shown that DPhe is the most critical amino acid for the binding and cAMP activities to hMCRs. ${ }^{43,73,75}$ The $N$ Me-DPhe ${ }^{7}$ substitution apparently led to a conformation which prevents interaction of the aromatic ring with the $3^{\text {rd }}$ and the $6^{\text {th }}$ transmembrane binding domains aromatic groups. ${ }^{76}$ The $\mathrm{NMe}-\mathrm{His}^{6}$ analog reveals increased binding selectivity for the hMC1R and hMC3R. This result parallels our earlier observation that constraining the His residue can lead to potent antagonists especially for the hMC3R. ${ }^{77}$

The second group of peptides are dimethylated derivatives in the core sequence of MT-II (peptides 7-16). In this group, some exciting results are observed. It is first demonstrated that any site of $N$-methylation combined with $N \mathrm{Me}-\mathrm{DPhe}^{7}$ will lose the binding as well as cAMP activities at all hMCRs (peptides $\mathbf{9 , 1 2 , 1 4 , 1 6}$ ) confirming the results from mono-methylation. $\mathrm{N}$-Methylation combined with $N \mathrm{Me}$-Lys reduces binding at the hMC4R and hMC5R (peptide $7, \mathbf{8}, \mathbf{1 0}$ ). The cAMP functional assays show that except 7 at the hMC5R these peptides retain partial agonist activities. $N$-Methylation combined with $N$ Me-Trp increases the selective agonist activity at the hMC1R (peptides 11, 13), and selective antagonist activity at hMC3R (peptide 13) and lead to large decreases in binding and functional activity at the hMC4R and hMC5R resulting in increased selectivity of peptide $\mathbf{1 2}$ for the hMC3R. The combination of $N \mathrm{Me}-\mathrm{His}$ and $N \mathrm{Me}-\mathrm{Arg}$ (peptide 15) reduces the binding at the hMC4R and the hMC5R, therefore increase the agonist selectivity for the hMC1R and hMC3R.

More interesting results are found in the $3^{\text {rd }}$ group of peptides (peptides 17-26), tri- $N$ methylated derivatives in the core sequence of MT-II caused a loss in binding affinities (peptides 18, 20, 22, 23, 25, 26), especially, with any of the combinations with $N M e-D P h e$. In this group, as long as DPhe is not $N$-methylated, most ligands will retain binding activity at hMCRs (peptides 17, 19, 21, 24), but they all have reduced cAMP activity (Table 2) except at the hMC1R (partial agonists). Tri- $N$-methylations generally increase the agonist selectivity for 
the hMC1R (peptides 17, 19, 21, 24). It can be seen from Table 1 that 24 has totally lost activity for all receptors but the hMC1R, which still exhibits good binding affinity and $>1000$ fold selectivity vs the hMC3, hMC4 and hMC5 receptors. The compound has agonist activity as well (Table 2).

Selectivity, but also loss of activity, are further shown for the five tetra- $N$-methylated MT-II derivatives (peptides 28-32). Tetra- $N$-methylation caused a loss in binding affinities and cAMP activities at all subtypes of hMCRs except for peptide 28, which has potent binding affinity (14 nmol) at the $\mathrm{hMC1R}$ and has full agonist activity. Thus, a highly potent and selective agonist of hMC1R has been obtained. Peptides 29,30 and especially 32 are weak, but selective antagonists for the hMC5R.

In addition to $31 N^{\alpha}$-methylated analogs, one $\varepsilon-N$-methylated lysine analogue (peptide 33 ) was investigated. It is interesting to note that in the case of peptide $\mathbf{3 3}$, there was a loss in binding to the hMC4R, while selective antagonist activity was seen for the hMC5R in the nanomolar range (peptide $\mathbf{3 3}$ is still a full agonist at the $\mathrm{hMC} 1 \mathrm{R}$ and the $\mathrm{hMC} 3 \mathrm{R}$ ). Thus far there are few cases of selective peptide antagonists at the hMC5R.

It has been demonstrated that the MC1R, which is activated selectively by the fourfold $N$ methylated peptide $\mathbf{2 8}$ is involved in pain, in immune response, and in melanoma cancer. ${ }^{78}$ Thus, highly selective MC1R ligands have potential for treatment of pigmentary disorders, $18-20,79,80$ treatment of pain, ${ }^{78}$ cancer therapy,${ }^{81,82}$ and inflammatory disorders of the skin. The hMC1R is just one subtype of hMCRs in the melanocortin system. It is mainly distributed in the peripheral system in mammals, and the other subtypes of hMCRs are distributed in both of the peripheral and the central nervous system. ${ }^{18}$ Designing highly constrained, lipophilic hMC1R selective N-methylated MT-II derivatives will have widest application for specific targeting of disease.

\section{NMR Conformational Studies}

The conformation of the highly potent and selective compound $\mathbf{2 8}$ (Figure 2) was investigated by NMR spectroscopy, restrained distance geometry calculations (DG), restrained $150 \mathrm{ps}$ MD simulation in explicit water (rMD) and by unrestrained $30 \mathrm{~ns}$ MD simulation in explicit water (MD). Based on NMR assignments (Table 3) and other NMR data (ROEs, homo- and heteronuclear scalar coupling constants, $\mathrm{H}^{\mathrm{N}}$ temperature gradients) and on restrained and unrestrained molecular dynamics a distinct and preferred structure could be derived for the peptide backbone. The amide bridged side chains of the residues Asp ${ }^{5}$ and $N \mathrm{Me}-\mathrm{Lys}{ }^{10}$ that are also part of the cyclic core were found to be flexible. The resulting good agreement between measured and calculated distances clearly indicates a preferred backbone conformation of the structure obtained from the restrained MD simulation (Table 4). ${ }^{83}$ In a very extended (30 ns) unrestrained MD simulation in explicit water this structure proved to be stable except for slight changes of four backbone dihedral angles in the range of $20^{\circ}$ to $40^{\circ}$ (Table 5). Indicators for a reliable structure can be seen in the predominantly parallel orientation of $\mathrm{CO}(\mathrm{i})$ to $\mathrm{C}^{\alpha} \mathrm{H}^{\alpha}$ (i $+1)$ bond vectors ${ }^{84}$ and in an overall high dispersion of backbone chemical shifts $\left(\mathrm{H}^{\alpha}: 4.231\right.$ to $6.021 \mathrm{ppm}$ (Figure 3), $\mathrm{H}^{\mathrm{Me}}$ : 1.559 to $3.115 \mathrm{ppm}$ ). In our hands a comparative attempt to discuss the spectral data of non- $N$-methylated MT-II by one single preferred conformation failed. There was considerable backbone dynamics as indicated by a high heterogeneity of the best 30 out of 50 MT-II conformers obtained from DG calculations (RMSD of the backbone carbon and nitrogen atoms of $1.26 \AA)$. Moreover, a low dispersion of chemical shifts $\left(\mathrm{H}^{\alpha}: 4.198\right.$ to $4.644 \mathrm{ppm}$ (Figure 3), $\mathrm{H}^{\mathrm{N}}: 7.871$ to $8.541 \mathrm{ppm}$ ), a lack of strong differentiation of all seven backbone $\mathrm{H}^{\mathrm{N}}$ temperature gradients $(-8.61$ to $-5.24 \mathrm{ppb} / \mathrm{K}$ ) and of amide proton exchange rates as estimated by ROESY exchange peaks, as well as a smaller preference of distinct sidechain conformations was observed. Altogether, these indicators suggest a more flexible peptide backbone of MT-II as compared to peptide $\mathbf{2 8}$. 


\section{Structure of the peptide backbone of 28}

The conformation of compound $\mathbf{2 8}$ is shown in Figure 4. The ROE pattern demonstrates that all peptide bonds are trans configurated. As most of the amide bonds are $\mathrm{N}$-methylated, turnstructures are not only defined by intramolecular hydrogen bonds. ${ }^{85}$ We think that steric effects and dipole orientation such as the above mentioned parallel orientation of $\mathrm{CO}(\mathrm{i})$ to $\mathrm{C}^{\alpha} \mathrm{H}^{\alpha}(\mathrm{i}+1)$ bond vectors ${ }^{84}$ contribute most strongly to the conformation of smaller $N$-methylated cyclic peptides.

According to the $N \mathrm{Me}-\mathrm{His}^{6}$ backbone dihedral angles $\left(\Phi=-98^{\circ}, \Psi=78^{\circ}\right)$ the structure obtained from restrained MD simulation possesses an inverted $\gamma$-turn ${ }^{85}$ centered at $N \mathrm{Me}-\mathrm{His}^{6}{ }^{6}$. A distance of $3.4 \AA$ between the Asp ${ }^{5}$ carbonyl oxygen and the $\mathrm{DPhe}^{7}$ amide nitrogen, a hydrogen bond angle of $141^{\circ}$ and a moderately negative temperature gradient of $\mathrm{DPhe}^{7} \mathrm{H}^{\mathrm{N}}(-5.92 \mathrm{ppb} /$ $\mathrm{K}$ in the aqueous buffer, $-5.55 \mathrm{ppb} / \mathrm{K}$ in DMSO) indicate that the hydrogen bond within this inverted $\gamma$-turn is rather weak and protection form the solvent is incomplete. According to the minimal requirement for $\beta$-turns, ${ }^{86}$ which consists in a distance of less than $7 \AA$ between $\mathrm{C}^{\alpha}{ }_{i}$ and $\mathrm{C}^{\alpha}{ }_{\mathrm{i}+3}$, the inverted $\gamma$-turn is located within a $\beta$-turn ranging from $\mathrm{Asp}^{5}$ to $N \mathrm{Me}-\mathrm{Arg}^{8}\left(\mathrm{C}^{\alpha}-\right.$ $\mathrm{C}^{\alpha}$ distance: $6.4 \AA$ ). A distance of $7.6 \AA$ between the $\alpha$-carbon atoms of $N \mathrm{Me}-\mathrm{His}^{6}$ and $N \mathrm{Me}-$ $\operatorname{Trp}^{9}$ almost fulfills the criterion for a second overlapping $\beta$-turn, which is close to type II' $\beta$ turn geometry, as $\mathrm{DPhe}^{7} \Phi, \mathrm{DPhe}^{7} \Psi, N \mathrm{Me}-\mathrm{Arg}^{8} \Phi$, and $N \mathrm{Me}-\mathrm{Arg}^{8} \Psi$ possess dihedral angles of $96^{\circ},-126^{\circ},-135^{\circ}$ and $80^{\circ}$, respectively. The overlapping turns result in a virtually complete helical twist ( $\alpha$-turn) that extends from residues Asp ${ }^{5}$ to $N$ Me-Trp ${ }^{9}$. Hydrophobic clustering of the $N$ Me-Trp ${ }^{9} N$-methyl group with the $\mathrm{Asp}^{5} \mathrm{H}^{\beta}, N \mathrm{Me}-\mathrm{Arg}^{8} \mathrm{H}^{\alpha}, N \mathrm{Me}-\mathrm{Lys}{ }^{10} \mathrm{H}^{\gamma}$ atoms and the $N \mathrm{Me}-\mathrm{His}^{6} \mathrm{~N}$-methyl group (indicated by the presence of ROESY cross peaks between the $N \mathrm{Me}-\operatorname{Trp}^{9}$ methyl protons and the Asp ${ }^{5} \mathrm{H}^{\beta}, N \mathrm{Me}-\mathrm{Arg}^{8} \mathrm{H}^{\alpha}, N \mathrm{Me}-\mathrm{Lys}^{10} \mathrm{H}^{\gamma}, N \mathrm{Me}-\mathrm{His}^{6}{ }^{6}$ methyl protons) seems to stabilize this helical twist. Within the unrestrained $30 \mathrm{~ns}$ MD simulation starting from the structure of the restrained MD, slight changes occurred in a few backbone dihedral angles as compared to the average structure from the restrained MD simulation. $\mathrm{Asp}^{5} \Psi, N \mathrm{Me}-\mathrm{His}^{6} \Psi, \mathrm{DPhe}^{7} \Phi$ and $N \mathrm{Me}-\operatorname{Trp}^{9} \Psi$ were most affected and changed from $144^{\circ}$ to $113^{\circ}, 78^{\circ}$ to $117^{\circ}, 96^{\circ}$ to $75^{\circ}$ and $63^{\circ}$ to $96^{\circ}$, respectively (Table 5). The RMSD between the atoms of the peptide backbone from Asp ${ }^{5}$ to $N \mathrm{Me}-\mathrm{Lys}{ }^{10}$ of structures obtained from the unrestrained and restrained MD simulation is $1.0 \AA$. According to the $\mathrm{NMe}-\mathrm{His}^{6}$ backbone dihedral angles $\left(\Phi=-102^{\circ}, \Psi=117^{\circ}\right)$ the inverted $\gamma$-turn is less pronounced in the structure obtained from unrestrained MD simulation. Upper bounds of some distance restraints within the cyclic core structure $\left(\mathrm{Asp}^{5} \mathrm{H}^{\beta}-\mathrm{DPhe}^{7} \mathrm{H}^{\mathrm{N}} ; \mathrm{Asp}^{5} \mathrm{H}^{\beta}-\mathrm{NMe}-\mathrm{His}^{6} \mathrm{H}^{\mathrm{Me}} ; \mathrm{DPhe}{ }^{7} \mathrm{H}^{\mathrm{N}}\right.$ $N$ Me-Arg ${ }^{8} \mathrm{H}^{\alpha} ; N \mathrm{Me}-\mathrm{Arg}^{8} \mathrm{H}^{\alpha}-N \mathrm{Me}-\mathrm{Lys}{ }^{10} \mathrm{H}^{\mathrm{Me}} ; N \mathrm{Me}-\operatorname{Trp}^{9} \mathrm{H}^{\mathrm{Me}}-N \mathrm{Me}-\mathrm{Lys}{ }^{10} \mathrm{H}^{\alpha}$ ) were violated during the unrestrained MD simulation. This can be traced back directly to the aforementioned changes in backbone dihedral angles. As illustrated in more detail in the sections describing the side chain dynamics and structure calculations, we think that the changes in the backbone dihedral angles were caused by artificial strains in the amide linked Asp ${ }^{5}$ and $N M e-L y s{ }^{10}$ sidechains. These were introduced within the DG calculation as our structure calculation protocol did not take conformational averaging explicitly into account. Accordingly, the conformer obtained from restrained MD seems to be the best structural model for the peptide backbone and we focused the analysis of side chain conformation on this structure.

In consideration of the high binding affinity to $\mathrm{hMC} 1 \mathrm{R}\left(\mathrm{IC}_{50}=14 \mathrm{~nm}\right)$ and the strong restriction that cyclization and fourfold $N$-methylation pose on conformational changes within the backbone of peptide $\mathbf{2 8}$, we think that its backbone conformation in aqueous solution is very close to the conformation present in the receptor bound state.

The conformation of the peptide backbone also offers an explanation for the strong interference of DPhe ${ }^{7} N$-methylation with hMCR affinity, as $N$-methylation goes in hand with an increased spatial requirement and increased hydrophobicity in comparison to the replaced amide proton. If DPhe ${ }^{7}$ is $N$-methylated, these hydrophobic and steric effects would prohibit the formation 
of the backbone conformation present in peptide $\mathbf{2 8}$, as close proximity between the Asp ${ }^{5}$ carbonyl oxygen and the $\mathrm{DPhe}^{7} \mathrm{~N}$-methyl group is disfavored. Hence, the $N \mathrm{Me}-\mathrm{DPhe} \mathrm{P}^{7}$ substitution would not simply displace a hydrogen bond donor, but also lead to an altered conformation of the peptide backbone, which would affect the presentation of the pharmacophore and prevent interaction of the aromatic ring with the $3^{\text {rd }}$ and the $6^{\text {th }}$ transmembrane binding domains aromatic groups. ${ }^{76}$

\section{Side chain structure and dynamics}

Investigation of side chain conformation about the $\chi_{1}$ angle requires a careful analysis of homoand heteronuclear J-couplings as well as the consideration of NOE distances in stereospecifically assigned $\beta$ protons. ${ }^{87}$ Extended MD simulations of a solution structure in explicit solvent can further clarify which structural flips of side chain dihedral angles are correlated.

The sums of the ${ }^{3} \mathrm{~J}_{\mathrm{H} \alpha-\mathrm{H} \beta}$ coupling constants of the individual amino acid side chains are in the order of $15 \mathrm{~Hz}$, which excludes higher populations of the $\chi_{1}=60^{\circ}$ conformation (gauche + ) for the $\mathrm{L}$ amino acid residues, and of the $\chi_{1}=-60^{\circ}$ conformation (gauche-) for the $\mathrm{DPhe}^{7}$ residue (Table 6). A strong difference between the two ${ }^{3} \mathrm{~J}_{\mathrm{H} \alpha-\mathrm{H} \beta}$ coupling constants together with a sum of both of about $15 \mathrm{~Hz}$ indicate however a preferred $\left(\chi_{1}=-60^{\circ}\right)$ conformation for Asp 5 $\left({ }^{3} \mathrm{~J}_{\mathrm{H} \alpha-\mathrm{H} \beta \mathrm{proS}}=10.7 \mathrm{~Hz}\right)$ and $N \mathrm{Me}-\operatorname{Trp}^{9}\left({ }^{3} \mathrm{~J}_{\mathrm{H} \alpha-\mathrm{H} \beta \text { proR }}=11.1 \mathrm{~Hz}\right)$, whereas $N \mathrm{Me}-\mathrm{His}^{6}$ and $N \mathrm{Me}-$ $\mathrm{Arg}^{8}$ with identical ${ }^{3} \mathrm{~J}_{\mathrm{H \alpha}-\mathrm{H} \beta \text { proR }}$ and ${ }^{3} \mathrm{~J}_{\mathrm{H \alpha}-\mathrm{H} \beta \text { proS }}$ coupling constants populate the $\chi_{1}=-60^{\circ}$ ) and $\left(\chi_{1}=180^{\circ}\right)$ conformations. For DPhe ${ }^{7}$ the difference of the ${ }^{3} \mathrm{~J}_{\mathrm{H} \alpha-\mathrm{H} \beta}$ coupling constants is small indicating a less pronounced preference of the $\chi_{1}=60^{\circ}$ over the $\chi_{1}=180^{\circ}$ rotamer. For $N \mathrm{Me}-\mathrm{Lys} \mathrm{s}^{10}$ the ${ }^{3} \mathrm{~J}_{\mathrm{H} \alpha-\mathrm{H} \beta}$ coupling constants indicate populations of 70 to $30 \%$ for the $\chi_{1}=-60^{\circ}$ and $\chi_{1}=180^{\circ}$ rotamers or vice versa. It is not clear, which of both is higher populated as the chemical shifts of the two $\beta$ protons are degenerated. The $N$ Me-Lys ${ }^{10} \mathrm{H}^{\zeta}$ signal is slightly broadened to a singlet of $18 \mathrm{~Hz}$ linewidth which has weak shoulders (see supporting information) but lacks the expected double duplet or triplet structure expected from the coupling to the two $\delta$-Protons when the NMR data is processed for signal intensity. Optimization of the linewidth by gaussian multiplication of the FID prior to Fourier transformation led to two similar ${ }^{3} \mathrm{~J}_{\mathrm{H} \varepsilon-\mathrm{H} \zeta}$ coupling constants of 6.5 to $7.0 \mathrm{~Hz}$. The similar ${ }^{3} \mathrm{~J}_{\mathrm{H} \alpha-\mathrm{H} \beta}$ coupling constants indicate an equilibrium of different conformers within the amide bridged Asp ${ }^{5}$ and $N$ Me-Lys ${ }^{10}$ side chains. The slightly broadened $N$ Me-Lys ${ }^{10} \mathrm{H}^{\zeta}$ signal further suggests that the underlying conformers exchange on a timescale slower than the ns regime what prohibits their sampling by MD simulation in explicit water.

Dynamics of the side chains that are not involved in cyclization were further investigated by $30 \mathrm{~ns}$ molecular dynamics simulations in explicit water (Figure 5). For analyzing the side chain dynamics based on the structure obtained from the rMD calculation, position restraints were applied on the carbon and nitrogen atoms of the peptide backbone from $\mathrm{Asp}^{5} \mathrm{C}^{\alpha}$ to $\mathrm{NMe}-$ Lys ${ }^{10} \mathrm{C}^{\alpha}$. Analysis of the MD simulation performed with such position restraints revealed that all $\chi_{1}$ populations except of the $\chi_{1}$ populations of $N \mathrm{Me}-\mathrm{Arg}^{8}$ and of $N \mathrm{Me}-\mathrm{Lys}{ }^{10}$ were well consistent with the ${ }^{3} \mathrm{~J}_{\mathrm{H \alpha}-\mathrm{H} \beta}$ coupling constants (Table 6, Figure 5). The strong preference of $\chi_{1}=-60^{\circ}$ for $\mathrm{Asp}^{5}$ and for $N \mathrm{Me}-\operatorname{Trp}^{9}$ as well as the evenly populated $\chi_{1}=-60^{\circ}$ and $\chi_{1}=180^{\circ}$ rotamers for $\mathrm{Nle}^{4}$ and $N \mathrm{Me}-\mathrm{His}^{6}$ are indicated by ${ }^{3} \mathrm{~J}_{\mathrm{H} \alpha-\mathrm{H} \beta}$ coupling constants and well reproduced by the MD simulation. For DPhe ${ }^{7}$, the preference of the $\chi_{1}=60^{\circ}$ rotamer with respect to the $\chi_{1}=180^{\circ}$ rotamer, that is indicated by the ${ }^{3} \mathrm{~J}_{\mathrm{H} \alpha-\mathrm{H} \beta}$ coupling constants, is not reflected by the MD trajectory, which suggests similar populations of the two rotamers.

As indicated by the MD simulation, by the ROEs and by the upfield or downfield chemical shifts, hydrophobic clustering is crucial for the different side chain conformations of peptide 28 in aqueous solution. Stacking of the $N$ Me-His ${ }^{6}$ and DPhe ${ }^{7}$ side chains, that was also reported in other structural investigations of $\alpha$-MSH analogs is well observed within the MD trajectory 
and is also present in the exemplary conformation shown in Figure 4A. Hydrophobic contacts between the $\mathrm{DPhe}^{7}$ and $N \mathrm{Me}-\mathrm{Arg}^{8}$ side chains that agree with strong upfield shifts of the $N \mathrm{Me}-\mathrm{Arg}^{8} \beta$ and $\gamma$ protons are also observed within the MD trajectory and depicted in the conformation shown in Figure 4B. Overall side chain dynamics as indicated by ${ }^{3} \mathrm{~J}_{\mathrm{H} \alpha-\mathrm{H} \beta}$ coupling constants, is reflected by the rotamers shown for $N \mathrm{Me}-\mathrm{His}^{6}, \mathrm{DPhe}^{7}$ and $N \mathrm{Me}-\mathrm{Arg}^{8}$ in Figure 4A and 4B, respectively. The clustering of the $N \mathrm{Me}-\operatorname{Trp}^{9}$ indolyl ring with the $N$ methyl group of $N \mathrm{Me}-\mathrm{Arg}^{8}$, which is observed in Figures $4 \mathrm{~A}$ and $4 \mathrm{~B}$, is confirmed by ROE contacts between methyl protons and all indolyl protons as well as by a strongly upfield shifted $\mathrm{H}^{\mathrm{Me}}$ resonance at $1.559 \mathrm{ppm}$. ROEs between the $\mathrm{NMe}-\mathrm{His}^{6}$ methyl protons and the $\mathrm{NMe}-$ $\operatorname{Trp}^{9} \delta 1$ and $\varepsilon 1$ protons as well as between DPhe ${ }^{7} \mathrm{H}^{\alpha}$ and $N M e-\operatorname{Trp}^{9} \mathrm{H}^{\varepsilon 1}$ are well consistent with the orientation of the indolyl ring given in Figure 4A and 4B. An additional ROE between the $N \mathrm{Me}-\mathrm{His}^{6}$ methyl protons and the $N \mathrm{Me}-\operatorname{Trp}^{9} \varepsilon 3$ proton indicates another orientation of the indolyl group that was not sampled during $30 \mathrm{~ns}$ unrestrained $\mathrm{MD}$ simulation. In this orientation the indolyl group also seems to stack on top of the $N \mathrm{Me}-\mathrm{Arg}^{8} \mathrm{~N}$-methyl group as shown in Figure 4 but with the six membered ring of the indolyl group pointing to the left and the five membered ring pointing to the right.

A dispersion of chemical shifts of peptide 28 in DMSO-d6 ( $\mathrm{H}^{\alpha}: 4.245$ to $5.824 \mathrm{ppm}$ (Figure 3), $\mathrm{H}^{\mathrm{Me}}: 1.893$ to $3.058 \mathrm{ppm}$ ), which is similar to the dispersion in the aqueous buffer $\left(\mathrm{H}^{\mathrm{a}}\right.$ : 4.231 to $6.021 \mathrm{ppm}$ (Figure 3), $\mathrm{H}^{\mathrm{Me}}$ : 1.559 to $3.115 \mathrm{ppm}$ ), indicates that hydrophobic interactions observed in aqueous buffer are also present in the slightly more hydrophobic DMSO. This suggests that such hydrophobic interactions might also be present in hMC1R bound state.

In addition it is often found that stronger conformational preference which is accompanied by stronger biological activity indicates a closer similarity to the bioactive conformation. To our experience these effects seem to be stronger than calculated from population of conformations. Maybe this can be attributed to the importance of entropic effects in the binding process.

\section{Comparison with structures of other peptidic GPCR effectors}

According to our knowledge, no inverted $\gamma$-turn centered at $\mathrm{His}^{6}$ has been described so far in structures of similar, but not $N$-methylated $\alpha$-MSH analogs, like MT-II. $\beta$-turns ranging from $\mathrm{Asp}^{5}$ to $\mathrm{Arg}^{8}$ have more frequently been described than $\beta$-turns ranging from His ${ }^{6}$ to $\operatorname{Trp}^{9}$ which agrees with the structure of 28 to such a degree as the distance between the Asp 5 and $N \mathrm{Me}-\mathrm{Arg}^{8} \alpha$ carbon atoms $(6.4 \AA)$ is smaller than the distance between the $N \mathrm{Me}-\mathrm{His}{ }^{6}$ to $N \mathrm{Me}$ $\operatorname{Trp}^{9} \alpha$ carbon atoms $(7.6 \AA) .88$ In spite of certain similarities with respect to the occurrence of $\beta$-turns, the presentation of the side chains of residues $N \mathrm{Me}-\mathrm{Arg}^{8}$ and $N \mathrm{Me}-\mathrm{Trp}^{9}$ differs strongly from MT-II. A structure investigation of MT-II suggested that the $\mathrm{Arg}^{8}$ side chain is pointing up from the peptide plane and the $\operatorname{Trp}^{9}$ side chain is below the peptide plane, when the backbone is oriented as shown in Figure $4 .{ }^{88}$ In contrast, the $N \mathrm{Me}-\mathrm{Arg}^{8}$ side chain of compound $\mathbf{2 8}$ is pointing down from the peptide plane and the $N M e-T r p^{9}$ side chain of compound 28 is pointing up. This provides further evidence that positively charged $\mathrm{Arg}^{8}$ is critical for hMC3R and hMC4R binding and functional activities both for the ligand and for the receptor. ${ }^{76,89,90}$ Our earlier chimeric and multiple receptor mutation work demonstrated that the positive charged $\mathrm{Arg}^{8}$ plays an important role in binding to the $3^{\text {rd }}$ transmembrane domain using the Asp ${ }^{122}$ and $\mathrm{Asp}^{126}$ residues of the hMC3R and hMC4R to achieve binding and functional activities. Multiple $N$-methylation increases the hydrophobicity of the ligand and further reduces the ability of the guanidyl group to interact with the $\mathrm{Asp}^{122}$, Asp ${ }^{126}$ to activate the hMCRs, ${ }^{76}$ leading to a loss in the binding and functional activity use. These strong structural differences suggest that the side chain presentation required for MCR activity varies strongly for the individual receptor subtypes. Inherent MT-II flexibility, ${ }^{88,89}$ seems to be high enough for the adaptation to the binding regions of the individual receptor subtypes, whereas 
28 possesses a rigid peptide backbone that hinders the pharmacophore of MT-II from interacting properly with the binding pockets of the hMC3R, hMC4R and hMC5R therefore leading to hMC1R selectivity.

Backbone dihedral angles of $96^{\circ},-126^{\circ},-135^{\circ}$ and $80^{\circ}$ for $\mathrm{DPhe}^{7} \Phi, \mathrm{DPhe}^{7} \Psi, N \mathrm{Me}-\mathrm{Arg}^{8}$ $\Phi$, and $N \mathrm{Me}-\mathrm{Arg}^{8} \Psi$, respectively, resemble type II' $\beta$-turn positions $\mathrm{i}+1$ and $\mathrm{i}+2$. This directed our attention on obvious similarities between peptide 28 and potent somatostatin analogs, ${ }^{91-}$ 93 which possess a type II' $\beta$-turn with an aromatic $\mathrm{D}$ amino acid residue in position $\mathrm{i}+1$ and a positively charged $\mathrm{L}$ amino acid residue in position $\mathrm{i}+2 .{ }^{6}$ Both bind selectively to distinct GPCR subtypes of individual GPCR families (peptide $\mathbf{2 8}$ to hMC1R, somatostatin to sst2 and sst5 of the SRIF receptors). Hydrophobic interactions between aromatic side chains stabilize the turn structure of somatostatin analogs, while hydrophobic interactions of the $N$ Me-Trp ${ }^{9}$ methyl group with Asp ${ }^{5}$ and $N \mathrm{Me}-\mathrm{Lys}{ }^{10}$ side chain protons are present in peptide 28 . These similarities in peptide structure and receptor selectivity suggest further similarities between $\alpha$-MSH analogs and somatostatin analogs with respect to their receptor subtype preference. For somatostatin the empirical correlation of $\mathrm{Lys}^{\gamma}$ upfield shifts with the potency of the ligands have been extensively used to predict activities. ${ }^{93}$ Possibly, comparable correlations between $\operatorname{Arg} \mathrm{H}^{\gamma}$ upfield shifts and potency could be found in $\alpha$-MSH analogs as well.

\section{DG calculations}

DG calculations resulted in a very homogeneous ensemble of compound $\mathbf{2 8}$ conformers that were in good agreement with the distance restraints and very similar to the structure shown in Figure 4 . The best 30 out of 50 calculated structures possessed an RMSD of $0.27+/-0.10 \AA$ with respect to the backbone nitrogen and carbon atoms of residues Asp ${ }^{5}$ to $N \mathrm{Me}-\mathrm{Lys}^{10}$. Although ${ }^{3} \mathrm{~J}$ coupling constants and broadening of the $N$ Me-Lys ${ }^{10} \mathrm{H}^{\zeta}$ signal indicated dynamics in the amide linked side chains, the structures obtained from DG possessed very similar homogeneous $N$ Me-Lys ${ }^{10} \chi_{1}$ and $\chi_{2}$ dihedral angles $\left(\chi_{1}=-55.2^{\circ}+/-2.01 \AA, \chi_{2}=-109^{\circ}+/-\right.$ $3.73^{\circ}$ ). The observation of only one preferred $\chi_{1}$ dihedral angle did not reflect the ${ }^{3} \mathrm{~J}_{\mathrm{H} \alpha-\mathrm{H} \beta}$ coupling constants (Table 6 ) and the only populated eclipsed $\chi_{2}$ rotamer was thermodynamically unfavorable. Apparently, conformation averaging in the $N \mathrm{Me}-\mathrm{Lys}^{10}$ side chain led to a number of conformation averaged distance restraints that forced the lactam bridged $N \mathrm{Me}$-Lys ${ }^{10}$ side chain into conformations during DG calculations that could not be highly populated at equilibrium.

\section{Restrained Molecular Dynamics calculations}

The best DG structure in respect of violations of experimental distance restraints was subjected to refinement by restrained molecular dynamics (rMD) calculation in explicit water. The average structure of the rMD calculation was very similar to the DG starting structure ( RMSD $=0.69 \AA$ with respect to backbone heavy atoms from $\mathrm{Asp}^{5}$ to $N \mathrm{Me}-\mathrm{Lys}^{10}$ ). Within the cyclic core structure significant changes occurred only in the $N$ Me-Lys ${ }^{10}$ side chain, that was strained in the starting conformer as side chain dihedral angles were eclipsed $\left(\chi_{2}=-111^{\circ}\right.$ and $\chi_{3}=-137^{\circ}$ ). As expected, the force field applied during restrained MD calculation rotated the dihedral angles within the $N$ Me-Lys ${ }^{10}$ side chain to thermodynamically feasible values $\left(\chi_{2}=\right.$ $-169^{\circ}$ and $\chi_{3}=163^{\circ}$ ).

\section{Unrestrained Molecular Dynamics calculations}

The average structure obtained from the rMD calculation was further refined by extended (30 ns) unrestrained MD simulation in explicit water. This lead to significant changes of some backbone dihedral angles (Table 5) that were accompanied by further conformational changes in the lactam bridged $N \mathrm{Me}-\mathrm{Lys}^{10}$ sidechain. The changes of backbone dihedral angles led to significant violations of distance restraints and $\operatorname{most}{ }^{3} \mathrm{~J}_{\mathrm{H} \alpha-\mathrm{H} \beta}$ coupling constants were not consistent with the $\chi_{1}$ populations extracted from the MD trajectory. Consistency 
with ${ }^{3} \mathrm{~J}_{\mathrm{H} \alpha-\mathrm{H} \beta}$ coupling constants and with distance restraints was much higher in a trajectory of an MD simulation in which the conformation of the peptide backbone obtained from rMD was conserved by applying position restraints on all backbone carbon and nitrogen atoms from $\operatorname{Asp}^{5} \mathrm{C}^{\alpha}$ to $N \mathrm{Me}-\mathrm{Lys}{ }^{10} \mathrm{C}^{\alpha}$.

We believe that the artificial strains in the lactam bridged side chains, that were described above, induced the conformational changes that were observed in the peptide backbone during 30 ns non-position restrained MD simulation. The slight variations in $\Phi$ and $\Psi$ dihedral angles seemed to be energetically less demanding than flips between individual staggered conformations within the $N \mathrm{Me}-\mathrm{Lys}^{10}$ side chain. Apparently, the backbone compensated for the strains within the lactam bridged side chains during the unrestrained MD simulation and position restraining of the backbone during the unrestrained MD simulation seems to be a legitimate way to avoid faulty changes of backbone dihedral angles.

\section{Conclusions}

Multiple $N$-methylation in MT-II led to several derivatives in which the affinity and activity for hMC1R could be retained, but simultaneously the binding affinity to the other 3 melanocortin receptors was completely lost. Hence, selectivity and retained activity was achieved in this way. A careful analysis of the conformation of the most active (13 nM) compound reveals a strong preference of one backbone conformation, which indicates a strongly reduced conformational space in comparison to the non-methylated MT-II. Hence, this work again shows that restriction of peptide backbone conformation resulted in strong receptor subtype selectivity with retained or even improved activity for an individual receptor subtype. This approach, discussed by us already a quarter of a century ago 94,95 is not achievable only by cyclization but can be further increased by multiple $N$-methylation. ${ }^{48}$ With an increasing extent of introduction of $N$-methyl groups into its backbone, MT-II derivatives lose their ability to bind to particular hMCRs out of the total family of melanocortin receptors. This leads in two cases (peptides $\mathbf{2 4}$ and $\mathbf{2 8}$ ) to highly selective and potent agonists for the $\mathrm{hMC1R}$, but also to antagonists and compounds with both, agonist and antagonist activities. These compounds possess multiple amide bonds that are $N$-methylated which was recently reported to be a possible key towards bioavailability ${ }^{5}$ and maybe also enhanced oral bioavailability 6 of peptides. Whereas the effect of $N$-methylation on receptor subtype selectivity is strongly supported by our results, the effect on pharmacological properties that has been improved in other examples ${ }^{4-6}$ has to be demonstrated for the $N$-methylated MT-II derivatives. These investigations are in progress.

\section{Experimental Section}

\section{Materials}

$N^{\alpha}$-Fmoc-amino acids, peptide coupling reagents, Rink amide MBHA resin and solvents were reagent grade and used without further purification unless otherwise noted. These chemicals were obtained from Aldrich, Novabiochem, Iris Biotech GmbH, Merck, NeoMPS, ORPEGEN Pharma and GLS. The following amino acids were used: Fmoc-Lys(Alloc)-OH, Fmoc-Trp (Boc)-OH, Fmoc-Arg(Pbf)-OH, Fmoc-DPhe-OH, Fmoc-His(Trt)-OH, Fmoc-Asp(OAllyl)$\mathrm{OH}$ and Fmoc-Nle-OH. The polypropylene reaction vessels (syringes with frits) were purchased from B. Braun Melsungen AG. The purity of the peptides was checked by analytical reverse-phase HPLC using an Amersham Pharmacia Biotech Äkta Basic 10F with a ODS-A C18 (120 W, $5 \mathrm{Xm}, 250 \mathrm{~mm} \times 4.6 \mathrm{~mm}$ ) column (Omnicrom YMC Europe $\mathrm{GmbH})$ monitored at 220 and $254 \mathrm{~nm}$ and by high resolution mass spectral analysis. 


\section{Synthesis}

The MT-II analogues were synthesized manually by the Fmoc-SPPS using methods described in refs. ${ }^{96}$ and ${ }^{97}$.

0.3 g Rink amide MBHA resin (4-(2',4'-dimethoxyphenyl-Fmoc-aminomethyl)-

phenoxyacetamido-norleucyl-MBHA resin) in a $10 \mathrm{~mL}$ syringe with a frit on the bottom was swollen in NMP ( $3 \mathrm{~mL})$ for $10 \mathrm{~min}$. The Fmoc protecting group on the Rink linker was removed by $20 \%$ piperidine in NMP $(1 \times 8 \mathrm{~min}, 1 \times 12 \mathrm{~min})$. The resin was washed with NMP $(5 \times 3$ $\mathrm{mL}$ ). The first $N^{\alpha}$-Fmoc-amino acid was coupled using preactivated ester ( 3 eq. $\mathrm{N}^{\alpha}$-Fmocamino acid, 3 eq. TBTU, 3 eq. HOBt and 8 eq. DIEA) in NMP. The coupling mixture was transferred into the syringe with the resin and shaken for $3 \mathrm{~h}$. Afterwards the resin was washed with NMP $(5 \times 3 \mathrm{~mL})$. Complete coupling was confirmed by HPLC monitoring. Therefore the resin was washed with DCM $(2 \times 3 \mathrm{~mL})$. A small amount of resin was taken out of the syringe and three drops of a mixture of trifluoracetic acid/triethylsilane/water $(95: 2.5: 2.5, \mathrm{v} / \mathrm{v} / \mathrm{v})$ was added. After $10 \mathrm{~min}$, acetonitrile and water were added, and after filtration, HPLC and ESIMS showed complete coupling. The peptide sequences were continued by consecutively coupling of the particular amino acids. $N$-Methylation was carried out after coupling of the corresponding amino acid. This procedure includes three steps. First, the $N$-terminal $N^{\alpha}$-Fmocdeprotected amino acid was protected as an $N^{\alpha}$-o-nitrobenzene sulfonamide by reaction with 5 eq. of $o$-nitrobenzenesulfonyl chloride ( $o$-NBS) and 10 eq. of collidine in NMP (15 minutes). The methylation was done under Mitsunobu conditions ${ }^{98}$ with 5 eq. of triphenylphosphine, 10 eq. of methanol and 5 eq. of diisopropyl azodicarboxylate (DIAD) in THF (10 minutes). Then the $o$-NBS group was removed with 10 eq. of 2-mercaptoethanol and 5 eq. of DBU in NMP (5 minutes). This deproctection procedure was repeated once. For the coupling of the next amino acid, 3 eq. HATU, 3 eq. HOAt and 8 eq. DIEA were used. After coupling of the last amino acid Fmoc-Nle-OH and Fmoc deprotection as described above, acetylation was achieved by treatment of the DCM washed resin $(3 \times 3 \mathrm{~mL})$ with acetic anhydride/DCM/DIEA $(25: 75: 2.5, \mathrm{v} / \mathrm{v} / \mathrm{v}, 3 \mathrm{~mL})$ for $30 \mathrm{~min}$ and washing of the resin with DCM $(5 \times 3 \mathrm{~mL})$. The next step was the removal of the $N^{3}$-Alloc group of Lys and the $\beta$-allyl group of Asp..$^{96,97,99}$ For this, a solution of $\mathrm{PhSiH}_{3}$ (24 eq.) in $1 \mathrm{~mL}$ DCM was added to the peptide resins. Then a solution of $\mathrm{Pd}\left(\mathrm{PPh}_{3}\right)_{4}(0.25$ eq.) in $2 \mathrm{~mL}$ DCM was added and the reaction allowed to proceed for $30 \mathrm{~min}$. The peptide resins were washed with $\mathrm{DCM}(3 \times 3 \mathrm{~mL})$, NMP $(2 \times 3 \mathrm{~mL})$, afterwards twice with $0.5 \%$ DIEA in DMF (v/v) and $0.5 \%$ sodium diethyldithiocarbamate trihydrate (DEDTC) in DMF (w/w) to remove any remaining traces of the Pd catalyst, ${ }^{100}$ followed by NMP $(5 \times 3 \mathrm{~mL})$. The macrocyclic lactam ring formation was then mediated by addition of TBTU ( 3 eq.), HOBt ( 3 eq.) and DIEA ( 8 eq.) for $3 \mathrm{~h}$. The cyclized peptides were cleaved off solid support using $3 \mathrm{~mL}$ trifluoracetic acid/triethylsilane/water (95:2.5:2.5, v/v/v, $1 \times 3 \mathrm{~h}, 1$ $\times 15 \mathrm{~min}$ ), and the crude peptides were precipitated by dropping the solution in chilled diethyl ether to give white to light yellow precipitates. The resulting peptide suspensions were centrifuged for $5 \mathrm{~min}$ at $4000 \mathrm{rpm}$, and the liquid was decanted. The crude peptides were washed with chilled diethyl ether $(2 \times 30 \mathrm{~mL})$, and after the final centrifugation, dried under vacuum over night. Purification was performed by HPLC using a ODS-A C18 $(120 \AA \AA, 5 \mu \mathrm{m}, 250 \mathrm{~mm}$ $\times 20 \mathrm{~mm}$ ) column (Omnicrom YMC Europe $\mathrm{GmbH}$ ) eluting with a linear gradient of acetonitrile and water containing $0.1 \%$ TFA. The products were obtained by lyophilisation of the appropriate fractions after removal of the acetonitrile by rotary evaporation. Analysis by analytical HPLC and HPLC-MS (Supporting Information) showed the peptides to be pure $(>95 \%)$. The purified peptides were isolated in $2-14 \%$ overall yields. 


\section{Biological Activity Assays}

\section{Receptor Binding Assay}

Competition binding experiments were carried out using whole HEK293 cells stably expressing human MC1, MC3, MC4, and MC5 receptors as described before.101-103 HEK293 cells transfected with hMCRs $101^{-103}$ were seeded on 96 -well plates 48 hours before assay (50,000 cells/well). For the assay, the cell culture medium was aspirated and the cells were washed once with a freshly prepared MEM buffer containing $100 \%$ minimum essential medium with Earle's salt (MEM, GIBCO), and $25 \mathrm{mM}$ sodium bicarbonate. Next, the cells were incubated for $40 \mathrm{~min}$ at $37^{\circ} \mathrm{C}$ with different concentrations of unlabeled peptide and labeled $\left[{ }^{125} \mathrm{I}\right]-\left[\mathrm{Nle}^{4}, \mathrm{DPhe}^{7}\right]-\alpha-\mathrm{MSH}$ (Perkin-Elmer Life Science, 20,000 cpm/well, $33.06 \mathrm{pM}$ ) diluted in a $125 \mu \mathrm{L}$ of freshly prepared binding buffer containing 100\% MEM, $25 \mathrm{mM}$ HEPES (pH 7.4), $0.2 \%$ bovine serum albumin, $1 \mathrm{mM} 1,10$-phenanthrolone, $0.5 \mathrm{mg} / \mathrm{L}$ leupeptin, 200 $\mathrm{mg} / \mathrm{L}$ bacitracin. The assay medium was subsequently removed, the cells were washed once with basic medium, and then lysed by the addition of $100 \mu \mathrm{L}$ of $0.1 \mathrm{M} \mathrm{NaOH}$ and $100 \mu \mathrm{L}$ of $1 \%$ Triton X-100. The lysed cells were transferred to $12 \times 75 \mathrm{~mm}$ borosilicate glass tubes, and the radioactivity was measured by a Wallac 1470 WIZARD Gamma Counter. The results are shown in Table 1.

\section{Adenylate Cyclase Assay}

HEK 293 cells transfected with human melanocortin receptors ${ }^{103}$ were grown to confluence in MEM medium (GIBCO) containing 10\% fetal bovine serum, 100 units $/ \mathrm{mL}$ penicillin and streptomycin, and $1 \mathrm{mM}$ sodium pyruvate. The cells were seeded on 96-well plates 48 hours before assay (50,000 cells/well). For the assay, the cell culture medium was removed and the cells were rinsed with $100 \mu \mathrm{L}$ of MEM buffer (GIBCO). An aliquot $(100 \mu \mathrm{L})$ of the Earle's balanced salt solution with $5 \mathrm{nM}$ isobutylmethylxanthine (IBMX) was placed in each well along for $1 \mathrm{~min}$ at $37^{\circ} \mathrm{C}$. Next, aliquots $(25 \mu \mathrm{L})$ of melanotropin peptides of varying concentration were added, and the cells were incubated for $3 \mathrm{~min}$ at $37^{\circ} \mathrm{C}$. The reaction was stopped by aspirating the assay buffer and adding $60 \mu \mathrm{L}$ ice-cold Tris/EDTA buffer to each well, then placing the plates in a boiling water bath for $7 \mathrm{~min}$. The cell lysates were then centrifuged for $10 \mathrm{~min}$ at $2,300 \mathrm{x}$ g. A $50 \mu \mathrm{L}$ aliquot of the supernatant was transferred to another 96-well plate and placed with $50 \mu \mathrm{L}\left[{ }^{3} \mathrm{H}\right] \mathrm{cAMP}$ and $100 \mu \mathrm{L}$ protein kinase A (PKA) buffer in an ice bath for 2-3 hours. The PKA buffer consisted of Tris/EDTA buffer with 60 $\mu \mathrm{g} / \mathrm{mL}$ PKA and $0.1 \%$ bovine serum albumin by weight. The incubation mixture was filtered through $1.0 \mu \mathrm{m}$ glass fiber filters in MultiScreen ${ }^{\mathrm{TM}}$-FB 96 -well plates (Millipore, Billerica, MA). The total $\left[{ }^{3} \mathrm{H}\right]$ cAMP was measured by a Wallac MicroBeta TriLux 1450 LSC and Luminescence Counter (PerkinElmer Life Science, Boston, MA). The cAMP accumulation data for each peptide analogue was determined with the help of a cAMP standard curve generated by the same method as described above. $\mathrm{IC}_{50}$ and $\mathrm{EC}_{50}$ values represent the mean of two experiments performed in triplicate. $\mathrm{IC}_{50}$ and $\mathrm{EC}_{50}$ estimates and their associated standard errors were determined by fitting the data using a nonlinear least squares analysis, with the help of GraphPad Prism 4 (GraphPad Software, San Diego, CA). The maximal cAMP produced at $10 \mu \mathrm{M}$ concentration of each ligand was compared to the amount of cAMP produced at $10 \mu \mathrm{M}$ concentration of the standard agonist MT-II, and is expressed in per cent (as \% max effect) in the Table 2. The antagonist properties of the lead compounds were evaluated by their ability to competitively displace the MT-II agonist in a dose-dependent manner, at up to $10 \mu \mathrm{M}$.

\section{Data Analysis}

$\mathrm{IC}_{50}$ and $\mathrm{EC}_{50}$ values represent the mean of two experiments performed in triplicate. $\mathrm{IC}_{50}$ and $\mathrm{EC}_{50}$ estimates and their associated standard errors were determined by fitting the data using 
a nonlinear least squares analysis, with the help of GraphPad Prism 4 (GraphPad Software, San Diego, CA).

\section{NMR Spectroscopy}

DQF-COSY, E.COSY, TOCSY, ROESY, ${ }^{13} \mathrm{C}-\mathrm{HMBC}$ and ${ }^{13} \mathrm{C}-\mathrm{HSQC}$ spectra were recorded at $298 \mathrm{~K}$ on a Bruker DMX spectrometer operating at $600 \mathrm{MHz}$. A COLOC spectrum ${ }^{104}$ was recorded at $298 \mathrm{~K}$ on a Bruker Avance III spectrometer operating at $600 \mathrm{MHz}$. A phase sensitive $\mathrm{HMBC}$ and a reference HSQC spectrum with offset and rf-amplitude-compensated BEBOP $^{105,106}$ and BIBOP pulses ${ }^{107,108}$ were detected at $298 \mathrm{~K}$ on a Bruker Avance III spectrometer operating at $750 \mathrm{MHz} \cdot{ }^{109,110}$ Samples were prepared in $50 \mathrm{mM}$ Sodium acetate$\mathrm{d}_{4}$ buffer $\left(\mathrm{pH} 4.5,10 \% \mathrm{D}_{2} \mathrm{O}, 0.05 \% \mathrm{NaN}_{3}\right)$ at concentrations of $12-38 \mathrm{mM}$. This low $\mathrm{pH}$ was chosen to keep hydrogen exchange induced line broadening small and to enhance comparability with numerous earlier structural studies on MCR effectors that were performed under the same conditions. Sodium 3-(trimethylsilyl)propionate-2,2,3,3-d4 $\left({ }^{1} \mathrm{H}\right.$ at $\left.0.000 \mathrm{ppm}\right)$ was used as internal standard. Data were processed with Topspin 1.3 software from Bruker. The homo- and heteronuclear experiments DQF-COSY, E.COSY, TOCSY, ROESY, and magnitude mode ${ }^{13} \mathrm{C}$-HMBC were performed with a spectral width of $11 \mathrm{ppm}$ for ${ }^{1} \mathrm{H}$ and $180 \mathrm{ppm}$ for ${ }^{13} \mathrm{C}$. Individual HSQC spectra covering aliphatic $\left({ }^{13} \mathrm{C}\right.$ offset $=35 \mathrm{ppm}$, spectral width $=50$ $\mathrm{ppm})$ and aromatic ${ }^{13} \mathrm{C}$ resonances $\left({ }^{13} \mathrm{C}\right.$ offset $=120 \mathrm{ppm}$, spectral width $\left.=30 \mathrm{ppm}\right)$ were detected. The phase sensitive HMBC spectrum and the reference HSQC spectrum were detected with a spectral width of $9 \mathrm{ppm}$ for ${ }^{1} \mathrm{H}$ and $190 \mathrm{ppm}$ for ${ }^{13} \mathrm{C}$. A COLOC spectrum was detected with spectral widths of $9.5 \mathrm{ppm}$ for ${ }^{1} \mathrm{H}$ and $190 \mathrm{ppm}$ for ${ }^{13} \mathrm{C}$. The increments in $\mathrm{t} 1$ and $\mathrm{t} 2$ were adjusted to the information extracted from the individual experiments, ranging from 384 to 2048 increments in 11 and from 4096 to 16384 complex data points in t2. Depending on the sample concentration and the individual experiments, 16 to 48 transients were averaged for each $\mathrm{t} 1$ value. A mixing time of $80 \mathrm{~ms}$ was used for TOCSY (spin lock field: $6 \mathrm{kHz}$; mixing sequence MLEV-17). Water signal suppression was achieved by WATERGATE techniques. 111 The sequential assignment was obtained from heteronuclear J correlations that were extracted from HSQC and HMBC spectra. A compensated ROESY experiment, which was used for the extraction of inter proton distances, was performed with $150 \mathrm{~ms}$ mixing time and a spin lock field of $4000 \mathrm{kHz} .112$ The volume integrals of the individually assigned crosspeaks were compensated for offset effects and converted into distance constraints using the isolated spin pair approximation.113 In order to compensate for watergate solvent signal suppression artifacts, of any two cross peaks representing an internuclear distance, the peak with the higher water resonance offset in the direct dimension was preferably considered for distance calculations. The ROESY cross-peak volumes were calibrated against the distance $\left(1.78 \AA\right.$ ) between the prochiral $N \mathrm{Me}-\mathrm{Lys}{ }^{10} \mathrm{H}^{\varepsilon}$ protons. Upper and lower distance limits were set to plus and minus $10 \%$ of the calculated distances, respectively. For distance restraints referring to non-stereospecifically assigned methylene protons, another $0.7 \AA$ was added on upper bounds as pseudoatoms and multiplicity corrections. For distance restraints referring to methyl protons, subtraction of $10 \%$ for the lower bounds was omitted and another $0.9 \AA$ was added on upper bounds as pseudoatoms and multiplicity corrections. 18 intraresidual, 36 sequential interresidual and 9 non-sequential interresidual ROE derived distance restraints were used for structure calculations, with restraints between the lactam bridged residues Asp ${ }^{5}$ and $N$ Me-Lys ${ }^{10}$ counted as sequential. ${ }^{3} \mathrm{~J}_{\mathrm{HN}-\mathrm{H} \alpha}$ coupling constants were determined from $1 \mathrm{D}{ }^{1} \mathrm{H}$ NMR spectra, ${ }^{3} \mathrm{~J}_{\mathrm{H} \alpha-\mathrm{H} \beta}$ coupling constants from E.COSY and heteronuclear ${ }^{3} \mathrm{~J}_{\mathrm{C}-\mathrm{H}}$ coupling constants from HMBC and reference HSQC spectra. ${ }^{109,110,114,115}$

\section{Structure calculations for 28}

The structural NMR refinement protocol included distance geometry (DG) calculations, energy minimizations, and molecular dynamics (MD) simulations. The DG program DISGEO was used to generate structures consistent with the 63 distance restraints derived from the ROEs. 
116, 117 The DG procedure started with the embedding of 50 structures using random metrization. The structures obtained from DG were evaluated according to the lowest total restraint violations and additionally counterchecked for close contacts of protons that did not show corresponding ROESY crosspeaks. Among 30 structures that were in best accordance with experimentally derived restraints, all had identical peptide backbone conformations.

Restrained MD calculations (rMD) were carried out employing the module DISCOVER of the INSIGHT II 2001 program (Biosym/MSI Inc.) with the CVFF force field. The ROE restraints were included with a force constant of $10 \mathrm{kcal} \mathrm{mol}^{-1} \AA^{-2}$. The calculations were done with the explicit-image model of periodic boundary conditions. The best structure resulting from the DG calculation was placed in a cubic box of length $30 \AA$ and soaked with water. After energy minimization using steepest descent and conjugate gradient, the system was heated gradually starting from $10^{\circ} \mathrm{K}$ and increasing to $50,100,150,200,250$ and $300^{\circ} \mathrm{K}$ in $1 \mathrm{ps}$ steps, each by direct scaling of velocities. The system was equilibrated for $50 \mathrm{ps}$ with temperature bath coupling. Coordinates were saved every $100 \mathrm{fs}$ for another $150 \mathrm{ps}$. The average structure of the $150 \mathrm{ps}$ rMD calculation was subjected to energy minimization and further investigated by unrestrained MD simulations.

The GROMACS 4.0 software package (www.gromacs.org) $)^{118-120}$ was used to perform unrestrained MD calculations. Visualization of the simulation trajectories was performed using the software packages VMD ${ }^{121}$ and SYBYL 8.0. ${ }^{122}$ The scripts g_cluster, g_dist and g_angle, that were used for analysis of the MD trajectory, were all packaged with GROMACS. The 53a6 united atom $\left(\mathrm{CH}, \mathrm{CH}_{2}\right.$ and $\mathrm{CH}_{3}$ groups represented as a single atom) forcefield, one of the GROMOS96 force fields, ${ }^{123}$ was used for the molecular dynamic simulations. Rigid SPC water which was constrained using SETTLE ${ }^{124}$ served as water model. Solute bonds were constrained by the SHAKE algorithm ${ }^{125}$ and temperature and pressure control was executed by Berendsen coupling. ${ }^{126}$ Periodic boundary conditions were employed on a octahedral simulation box, which was built with a distance of $1.4 \mathrm{~nm}$ for the solute. Cut off distances of $1.4 \mathrm{~nm}$ for electrostatic and Lennard-Jones non-bonding interactions were applied. Simulation time steps were set to $2 \mathrm{fs}$. Upon addition of two acetate counter ions and soaking of the box with water, the system was equilibrated by an initial minimization and subsequent $50 \mathrm{ps}$ MD simulations at 50,100, 150, 200, 250 and $298 \mathrm{~K}$ using position restraints. Within the individual MD steps, the temperature was gradually increased, while the force constants of the position restraints were decreased exponentially from $250000 \mathrm{KJmol}^{-1} \mathrm{~nm}^{-2}$ at $50^{\circ} \mathrm{K}$ to $25^{\circ}$

$\mathrm{KJmol}^{-1} \mathrm{~nm}^{-2}$ at $250^{\circ} \mathrm{K}$. At $298 \mathrm{~K}$ no position restraints were applied. For adjacent pressure equilibration a $100 \mathrm{ps}$ MD simulation was performed at $298 \mathrm{~K}$. The final $30 \mathrm{~ns}$ MD simulation was carried out at $298^{\circ} \mathrm{K}$. Coordinates were saved every $10 \mathrm{ps}$. For the MD simulation with strict conservation of the peptide backbone obtained from the restrained MD simulation, position restraints of $250000 \mathrm{KJmol}^{-1} \mathrm{~nm}^{-2}$ were applied on all backbone carbon and nitrogen atoms between $\mathrm{Asp}^{5} \mathrm{C}^{\alpha}$ and $N \mathrm{Me}-\mathrm{Lys}{ }^{10} \mathrm{C}^{\alpha}$.

\section{Supplementary Material}

Refer to Web version on PubMed Central for supplementary material.

\section{Acknowledgments}

These studies were supported in parts by grants from the U.S. Public Health Service, National Institutes of Health, DK017420 and DA06284. We also thank the Humboldt Foundation for the support via the Max-Planck Award, the Deutschen Forschungsgemeinschaft (DFG) for financial support and Prof. Eberle in Basel for initial measurements of activities. JGB thanks Oliver Demmer for help with GROMACS and Dr. Burkhard Luy for help with HMBC and reference HSQC spectra. 


\section{References}

1. Lindenberg H. J Prakt Chem 1875;12:244-259.

2. Fischer E, Bergmann M. Liebigs Ann Chem 1913;398:96-124.

3. Fischer E, Lipschitz W. Ber Dtsch Chem Ges 1915;48:360-378.

4. Gilon, C.; Dechantsreiter, MA.; Burkhart, F.; Frieder, A.; Kessler, H. Houben-Weyl Methods of Organic Chemistry. Vol. E22c. Georg Theime Verlag; Stuttgart: 2003. p. 215-271.

5. Chatterjee J, Gilon C, Hoffman A, Kessler H. Acc Chem Res 2008;41:1331-1342. [PubMed: 18636716]

6. Biron E, Chatterjee J, Ovadia O, Langenegger D, Brueggen J, Hoyer D, Schmid HA, Jelinek R, Gilon C, Hoffman A, Kessler H. Angew Chem, Int Ed 2008;47:2595-2599.

7. Smith JM, Hows JM, Gordon-Smith EC. J Clin Pathol 1983;36:41-43. [PubMed: 6822676]

8. Sangalli L, Bortolotti A, Jiritano L, Bonati M. Drug Metab Dispos 1988;16:749-753. [PubMed: 2906601]

9. Al-Obeidi F, Hadley ME, Pettitt BM, Hruby VJ. J Am Chem Soc 1989;111:3413-3416.

10. Al-Obeidi F, Castrucci AM, Hadley ME, Hruby VJ. J Med Chem 1989;32:2555-2561. [PubMed: 2555512]

11. The Melanotropic Peptides. Ann N Y Acad Sci 1993;680:1-687.

12. Chhajlani V, Wikberg JE. FEBS Lett 1992;309:417-420. [PubMed: 1516719]

13. Chhajlani V, Muceniece R, Wikberg JE. Biochem Biophys Res Commun 1993;195:866-873. [PubMed: 8396929]

14. Gantz I, Konda Y, Tashiro T, Shimoto Y, Miwa H, Munzert G, Watson SJ, DelValle J, Yamada T. J Biol Chem 1993;268:8246-8250. [PubMed: 8463333]

15. Gantz I, Miwa H, Konda Y, Shimoto Y, Tashiro T, Watson SJ, DelValle J, Yamada T. J Biol Chem 1993;268:15174-15179. [PubMed: 8392067]

16. Gantz I, Shimoto Y, Konda Y, Miwa H, Dickinson CJ, Yamada T. Biochem Biophys Res Commun 1994;200:1214-1220. [PubMed: 8185570]

17. Labbe O, Desarnaud F, Eggerickx D, Vassart G, Parmentier M. Biochemistry 1994;33:4543-4549. [PubMed: 8161509]

18. The Melanocortin System. Ann N Y Acad Sci 2003;994:1-367. provides the proceedings of a recent symposium discussing the latest developments in this area.

19. Hadley, ME. The Melanotropin Peptides. CRC Press; Boca Raton, FL: 1989.

20. Eberle, AN. The Melanotropins: Chemistry, Physiology and Mechanisms of Action. Karger; Basel: 1988.

21. Manna SK, Aggarwal BB. J Immunol 1998;161:2873-2880. [PubMed: 9743348]

22. Maaser C, Kannengiesser K, Specht C, Lugering A, Brzoska T, Luger TA, Domschke W, Kucharzik T. Gut 2006;55:1415-1422. [PubMed: 16543288]

23. Xia Y, Wikberg JE. Cell Tissue Res 1996;286:63-68. [PubMed: 8781213]

24. Buckley DI, Ramachandran J. Proc Natl Acad Sci U S A 1981;78:7431-7435. [PubMed: 6278474]

25. Low MJ. J Endocrinol Invest 2004;27:95-100. [PubMed: 15481808]

26. Li SJ, Varga K, Archer P, Hruby VJ, Sharma SD, Kesterson RA, Cone RD, Kunos G. J Neuroscience 1996;16:5182-5188.

27. Gantz I, Fong TM. Am J Physiol Endocrinol Metab 2003;284:E468-474. [PubMed: 12556347]

28. Fan W, Boston BA, Kesterson RA, Hruby VJ, Cone RD. Nature 1997;385:165-168. [PubMed: 8990120]

29. Farooqi IS, Keogh JM, Yeo GS, Lank EJ, Cheetham T, O’Rahilly S. N Engl J Med 2003;348:10851095. [PubMed: 12646665]

30. Branson R, Potoczna N, Kral JG, Lentes KU, Hoehe MR, Horber FF. N Engl J Med 2003;348:10961103. [PubMed: 12646666]

31. Wessells H, Gralnek D, Dorr R, Hruby VJ, Hadley ME, Levine N. Urology 2000;56:641-646. [PubMed: 11018622] 
32. Wessells H, Levine N, Hadley ME, Dorr R, Hruby V. Int J Impot Res 2000;12(Suppl 4):S74-79. [PubMed: 11035391]

33. King SH, Mayorov AV, Balse-Srinivasan P, Hruby VJ, Vanderah TW, Wessells H. Curr Top Med Chem 2007;7:1098-1106. [PubMed: 17584130]

34. Eberle A, Hübscher W. Helv Chim Acta 1979;62:2460-2483.

35. Eberle A, Schwyzer R. Helv Chim Acta 1979;62:2452-2459.

36. Medzihradszky, K. Recent Developments in the Chemistry of Natural Carbon Compounds. Hungarian Academy of Science; Budapest: 1976. p. 207-250.

37. Schwyzer, R.; Eberle, A. Frontiers of Hormone Research. 4. Karger; Basel: 1977. p. 18-25.

38. Hruby VJ, Wilkes BC, Hadley ME, Al-Obeidi F, Sawyer TK, Staples DJ, de Vaux AE, Dym O, Castrucci AM, Hintz MF, Riehm JP, Rao KR. J Med Chem 1987;30:2126-2130. [PubMed: 2822931]

39. Castrucci AM, Hadley ME, Sawyer TK, Wilkes BC, Al-Obeidi F, Staples DJ, de Vaux AE, Dym O, Hintz MF, Riehm JP, Rao KR, Hruby VJ. Gen Comp Endocrinol 1989;73:157-163. [PubMed: 2537778]

40. Hruby VJ, Cai M, Grieco P, Han G, Kavarana M, Trivedi D. Ann N Y Acad Sci 2003;994:12-20. [PubMed: 12851293]

41. Hruby VJ, Cai M, Cain JP, Mayorov AV, Dedek MM, Trivedi D. Curr Top Med Chem 2007;7:11071119. [PubMed: 17584128]

42. Rajeswaran WG, Hocart SJ, Murphy WA, Taylor JE, Coy DH. J Med Chem 2001;44:1416-1421. [PubMed: 11311064]

43. Laufer R, Gilon C, Chorev M, Selinger Z. J Biol Chem 1986;261:10257-10263. [PubMed: 2426259]

44. Laufer R, Wormser U, Friedman ZY, Gilon C, Chorev M, Selinger Z. Proc Natl Acad Sci U S A 1985;82:7444-7448. [PubMed: 2414777]

45. Kawasaki, AM.; Knapp, R.; Wire, W.; Kramer, T.; Yamamura, HI.; Burks, TF.; Hruby, VJ. Eleventh American Peptide Symposium; 1990.

46. Hruby VJ, Fang SA, Knapp R, Kazmierski W, Lui GK, Yamamura HI. Int J Pept Protein Res 1990;35:566-573. [PubMed: 2401597]

47. Knapp RJ, Vaughn LK, Fang SN, Bogert CL, Yamamura MS, Hruby VJ, Yamamura HI. J Pharmacol Exp Ther 1990;255:1278-1286. [PubMed: 2262906]

48. Chatterjee J, Ovadia O, Zahn G, Marinelli L, Hoffman A, Gilon C, Kessler H. J Med Chem 2007;50:5878-5881. [PubMed: 17973471]

49. Cody WL, He JX, Reily MD, Haleen SJ, Walker DM, Reyner EL, Stewart BH, Doherty AM. J Med Chem 1997;40:2228-2240. [PubMed: 9216842]

50. Haviv F, Fitzpatrick TD, Swenson RE, Nichols CJ, Mort NA, Bush EN, Diaz G, Bammert G, Nguyen A, Rhutasel NS, Nellans HN, Hoffman DJ, Johnson ES, Greer J. J Med Chem 1993;36:363-369. [PubMed: 8381183]

51. Fairlie DP, Abbenante G, March DR. Curr Med Chem 1995;2:654-686.

52. Tonelli AE. Biopolymers 1976;15:1615-1622. [PubMed: 963253]

53. Manavalan P, Momany FA. Biopolymers 1980;19:1943-1973. [PubMed: 6776998]

54. Ron D, Gilon C, Hanani M, Vromen A, Selinger Z, Chorev M. J Med Chem 1992;35:2806-2811. [PubMed: 1495013]

55. Dechantsreiter MA, Planker E, Mathä B, Lohof E, Hölzemann G, Jonczyk A, Goodman SL, Kessler H. J Med Chem 1999;42:3033-3040. [PubMed: 10447947]

56. Ali FE, Bennett DB, Calvo RR, Elliott JD, Hwang SM, Ku TW, Lago MA, Nichols AJ, Romoff TT, Shah DH, Vasko JA, Wong AS, Yellin TO, Yuan CK, Samanen JM. J Med Chem 1994;37:769-780. [PubMed: 8145226]

57. Mazur RH, James PA, Tyner DA, Hallinan EA, Sanner JH, Schulze R. J Med Chem 1980;23:758763. [PubMed: 7401103]

58. Vitoux B, Aubry A, Cung MT, Marraud M. Int J Pept Protein Res 1986;27:617-632.

59. Sugano H, Higaki K, Miyoshi M. Bull Chem Soc Jpn 1973;46:226-230.

60. Aumailley M, Gurrath M, Müller G, Calvete J, Timpl R, Kessler H. FEBS Lett 1991;291:50-54. [PubMed: 1718779] 
61. Dechantsreiter, MA.; Mathä, B.; Jonczyk, A.; Goodman, SL.; Kessler, H. Peptides 1996. Mayflower Scientific; Kingswinford: 1996. p. 329

62. Shemyakin MM, Ovchinnkov YA, Ivanov VT, Kiryushkin AA. Tetrahedron 1963;19:581-591. [PubMed: 5879163]

63. Bevan K, Davies JS, Hall MJ, Hassall CH, Morton RB, Phillips DA, Ogihara Y, Thomas WA. Experientia 1970;26:122-123. [PubMed: 4905294]

64. Corbaz R, Ettlinger L, Gaumann E, Keller-Schierlein W, Kradolfer F, Neipp L, Prelog V. Helv Chim Acta 1957;23:199.

65. Jolad SD, Hoffmann JJ, Torrance SJ, Wiedhopf RM, Cole JR, Arora SK, Bates RB, Gargiulo RL, Kriek GR. J Am Chem Soc 1977;99:8040-8044. [PubMed: 591683]

66. Pettit GR, Kamano Y, Dufresne C, Cerny RL, Herald CL, Schmidt JM. J Org Chem 1989;54:6005.

67. Pettit GR, Kamano Y, Herald CL, Tuinman AA, Boettner FE, Kizu H, Schmidt JM, Baczynskyj L, Tomer KB, Bontems RJ. J Am Chem Soc 1987;109:6883-6885.

68. Ruegger A, Kuhn M, Lichti H, Loosli HR, Huguenin R, Quiquerez C, von Wartburg A. Helv Chim Acta 1976;59:1075. [PubMed: 950308]

69. Biron E, Kessler H. J Org Chem 2005;70:5183-5189. [PubMed: 15960522]

70. Miller SC, Scanlan TS. J Am Chem Soc 1997;119:2301-2302.

71. Biron E, Chatterjee J, Kessler H. J Pept Sci 2006;12:213-219. [PubMed: 16189816]

72. Teixido M, Albericio F, Giralt E. J Pept Res 2005;65:153-166. [PubMed: 15705160]

73. Haskell-Luevano C, Miwa H, Dickinson C, Hruby VJ, Yamada T, Gantz I. Biochem Biophys Res Commun 1994;204:1137-1142. [PubMed: 7980588]

74. Haskell-Luevano C, Sawyer TK, Hendrata S, North C, Panahinia L, Stum M, Staples DJ, Castrucci AM, Hadley MF, Hruby VJ. Peptides 1996;17:995-1002. [PubMed: 8899819]

75. Sawyer TK, Sanfilippo PJ, Hruby VJ, Engel EH, Heward CB, Burnett JB, Hadley ME. Proc Natl Acad Sci USA 1980;77:5754-5758. [PubMed: 6777774]

76. Chen M, Cai M, Aprahamian CJ, Georgeson KE, Hruby V, Harmon CM, Yang Y. J Biol Chem 2007;282:21712-21719. [PubMed: 17545153]

77. Grieco P, Cai M, Han G, Trivedi D, Campiglia P, Novellino E, Hruby VJ. Peptides 2007 28:11911196.

78. Mogil JS, Wilson SG, Chesler EJ, Rankin AL, Nemmani KVS, Lariviere WR, Groce MK, Wallace MR, Kaplan L, Staud R, Ness TJ, Glover TL, Stankova M, Mayorov A, Hruby VJ, Grisel JE, Fillingim RB. Proc Natl Acad Sci USA 2003;100:4867-4872. [PubMed: 12663858]

79. Dorr RT, Dvorakova K, Brooks C, Lines R, Levine N, Schram K, Miketova P, Hruby VJ, Alberts DS. Protochem Photobiol 2000;72:526-532.

80. Hadley ME, Hruby VJ, Sharma SD, Dorr RT, Levine N. Ann New York Acad Sci 1993;680:424439. [PubMed: 8390162]

81. Sharma SD, Jiang J, Hadley ME, Bentley DL, Hruby VJ. Proc Natl Acad Sci USA 1996;93:1371513720. [PubMed: 8943000]

82. Jiang J, Sharma SD, Fink JL, Hadley ME, Hruby VJ. Experimental Dermatol 1996;5:325-333.

83. Kessler H, Griesinger C, Lautz J, Müller A, van Gunsteren WF, Berendsen HJC. J Am Chem Soc 1988;110:3393-3396.

84. Heller M, Sukopp M, Tsomaia N, John M, Mierke DF, Reif B, Kessler H. J Am Chem Soc 2006;128:13806-13814. [PubMed: 17044709]

85. Matthews BW. Macromolecules 1972;5:818-819.

86. Venkatachalam CM. Biopolymers 1968;6:1425-1436. [PubMed: 5685102]

87. Kessler H, Griesinger C, Wagner K. J Am Chem Soc 1987;109:6927-6933.

88. Ying J, Kover KE, Gu X, Han G, Trivedi DB, Kavarana MJ, Hruby VJ. Biopolymers 2003;71:696716. [PubMed: 14991679]

89. Frändberg P-A, Xu X, Chhajlani V. Biochem Biophy Res Commun 1997;236:489-492.

90. Grieco P, Balse PM, Weinberg D, MacNeil T, Hruby VJ. J Med Chem 2000;43:4998-5002. [PubMed: 11150170] 
91. Veber DF, Holly FW, Paleveda WJ, Nutt RF, Bergstrand SJ, Torchiana M, Glitzer MS, Saperstein R, Hirschmann R. Proc Natl Acad Sci U S A 1978;75:2636-2640. [PubMed: 208068]

92. Sukopp M, Schwab R, Marinelli L, Biron E, Heller M, Varkondi E, Pap A, Novellino E, Keri G, Kessler H. J Med Chem 2005;48:2916-2926. [PubMed: 15828830]

93. Arison BH, Hirschmann R, Veber DF. Bioorg Chem 1978;7:447-451.

94. Kessler H. Angew Chem, Int Ed 1982;21:512-523.

95. Hruby VJ. Life Sci 1982;31:189-199. [PubMed: 6126794]

96. Mayorov AV, Han SY, Cai M, Hammer MR, Trivedi D, Hruby VJ. Chem Biol Drug Des 2006;67:329_ 335. [PubMed: 16784457]

97. Heckmann D, Kessler H. Methods Enzymol 2007;426:463-503. [PubMed: 17697896]

98. Mitsunobu O. Synthesis 1981;1:1-28.

99. Thieriet N, Alsina J, Giralt E, Guibe F, Albericio F. Tetrahedron Lett 1997;38:7275-7278.

100. Mayorov AV, Cai M, Chandler KB, Petrov RR, VanScoy AR, Yu Z, Tanaka DK, Trivedi D, Hruby VJ. J Med Chem 2006;49:1946-1952. [PubMed: 16539382]

101. Cai M, Mayorov AV, Ying J, Stankova M, Trivedi D, Cabello C, Hruby VJ. Peptides 2005;26:14811485. [PubMed: 15876475]

102. Cai M, Mayorov AV, Cabello C, Stankova M, Trivedi D, Hruby VJ. J Med Chem 2005;48:1839_ 1848. [PubMed: 15771429]

103. Cai M, Cai C, Mayorov AV, Xiong C, Cabello CM, Soloshonok VA, Swift JR, Trivedi D, Hruby VJ. J Pept Res 2004;63:116-131. [PubMed: 15009533]

104. Kessler H, Griesinger C, Zarbock J, Loosli HR. J Magn Reson 1984;57:331-336.

105. Skinner TE, Reiss TO, Luy B, Khaneja N, Glaser SJ. Journal of Magnetic Resonance 2003;163:815. [PubMed: 12852902]

106. Skinner TE, Reiss TO, Luy B, Khaneja N, Glaser SJ. Journal of Magnetic Resonance 2004;167:6874. [PubMed: 14987600]

107. Kobzar K, Skinner TE, Khaneja N, Glaser SJ, Luy B. Journal of Magnetic Resonance 2004;170:236243. [PubMed: 15388086]

108. Luy B, Kobzar K, Skinner TE, Khaneja N, Glaser SJ. Journal of Magnetic Resonance 2005;176:179_ 186. [PubMed: 16009584]

109. Verdier L, Sakhaii P, Zweckstetter M, Griesinger C. J Magn Reson 2003;163:353-359. [PubMed: 12914852]

110. Kobzar K, Luy B. J Magn Reson 2007;186:131-141. [PubMed: 17336556]

111. Piotto M, Saudek V, Sklenár V. J Biomol NMR 1992;2:661-665. [PubMed: 1490109]

112. Griesinger C, Ernst R. J Magn Reson 1987;75:261-271.

113. Kumar A, Wagner G, Ernst R, Wuethrich K. J Am Chem Soc 1981;103:3654-3658.

114. Eberstadt M, Gemmecker G, Mierke DF, Kessler H. Angew Chem, Int Ed 1995;34:1671-1695.

115. Richardson JM, Titman JJ, Keeler J, Neuhaus D. J Magn Reson 1991;93:533-553.

116. Mierke DF, Kessler H. Biopolymers 1993;33:1003-1017. [PubMed: 8343582]

117. Havel TF. Prog Biophys Mol Biol 1991;56:43-78. [PubMed: 1947127]

118. Lindahl E, Hess B, van der Spoel D. J Mol Model 2001;7:306-317.

119. van der Spoel D, Lindahl E, Hess B, Groenhof G, Mark AE, Berendsen HJC. J Comput Chem 2005;26:1701-1718. [PubMed: 16211538]

120. van der Spoel, D.; Lindahl, E.; Hess, B.; van Buuren, AR.; Apol, PJ.; Meulenhoff, PJ.; Tieleman, DP.; Sijbers, ALTM.; Feenstra, KA.; van Drunen, R.; Berendsen, HJC. Gromacs User Manual version 40. 2005.

121. Humphrey W, Dalke A, Schulten K. J Mol Graph 1996;14:33-38. 27-38. [PubMed: 8744570]

122. SYBYL 7.3. Tripos International; 1699 South Hanley Rd., St. Louis, Missouri, 63144, USA:

123. van Gunsteren, WF.; Billeter, SR.; Eising, AA.; Hunenberger, PH.; Krueger, P.; Mark, AE.; Scott, WRP.; Tironi, IG. Biomolecular simulation: the GROMOS96 manual and user guide. 1. Hochschulverlag AG an der ETH Zürich; Zürich: 1996.

124. Miyamoto S, Kollman PA. J Comput Chem 1992;13:952-962. 
125. Ryckaert JP, Ciccotti G, Berendsen HJC. J Comput Phys 1977;23:327-341.

126. Berendsen HJC, Postma JPM, van Gunsteren WF, Dinola A, Haak JR. J Chem Phys 1984;81:36843690. 


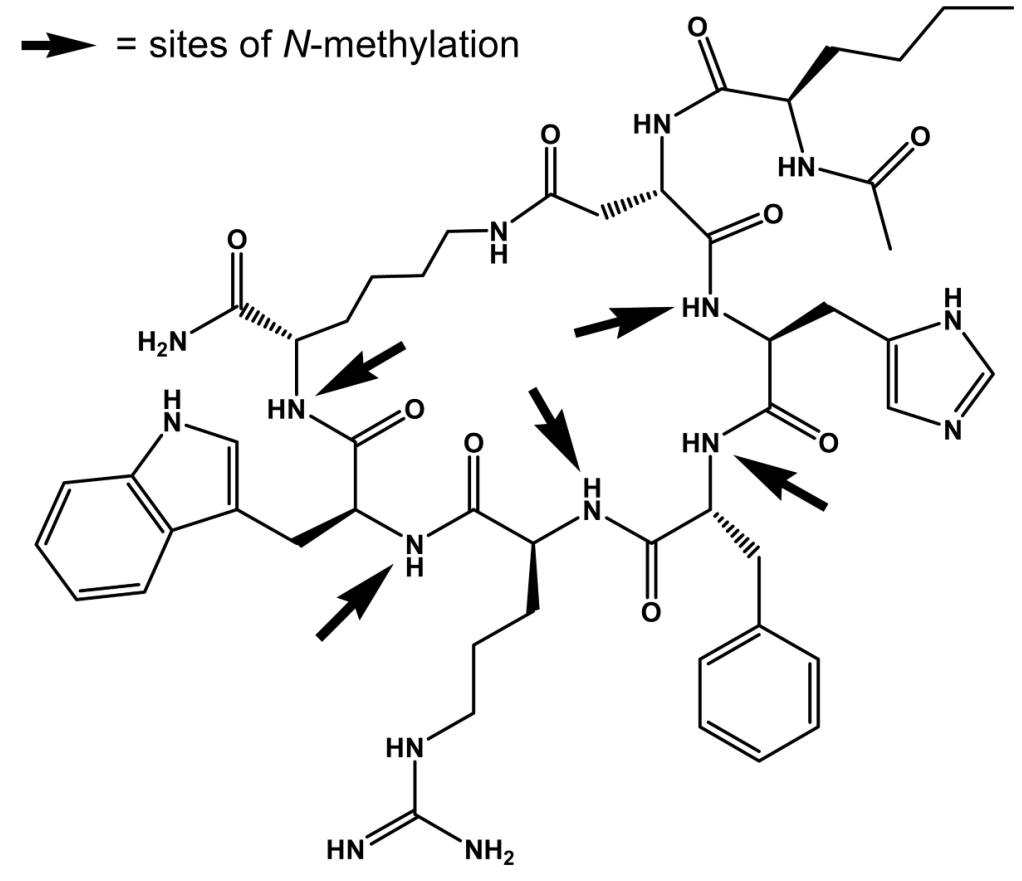

Figure 1.

MT-II (Ac-Nle-cyclo $(5 \beta \rightarrow 10 \varepsilon)\left(\right.$ Asp $^{5}$-His $^{6}{ }^{6} \mathrm{DPhe}^{7}-\mathrm{Arg}^{8}-\mathrm{Trp}^{9}$-Lys $\left.\left.^{10}\right)-\mathrm{NH}_{2}\right)$ with sites of $N$ methylation indicated by arrows. 


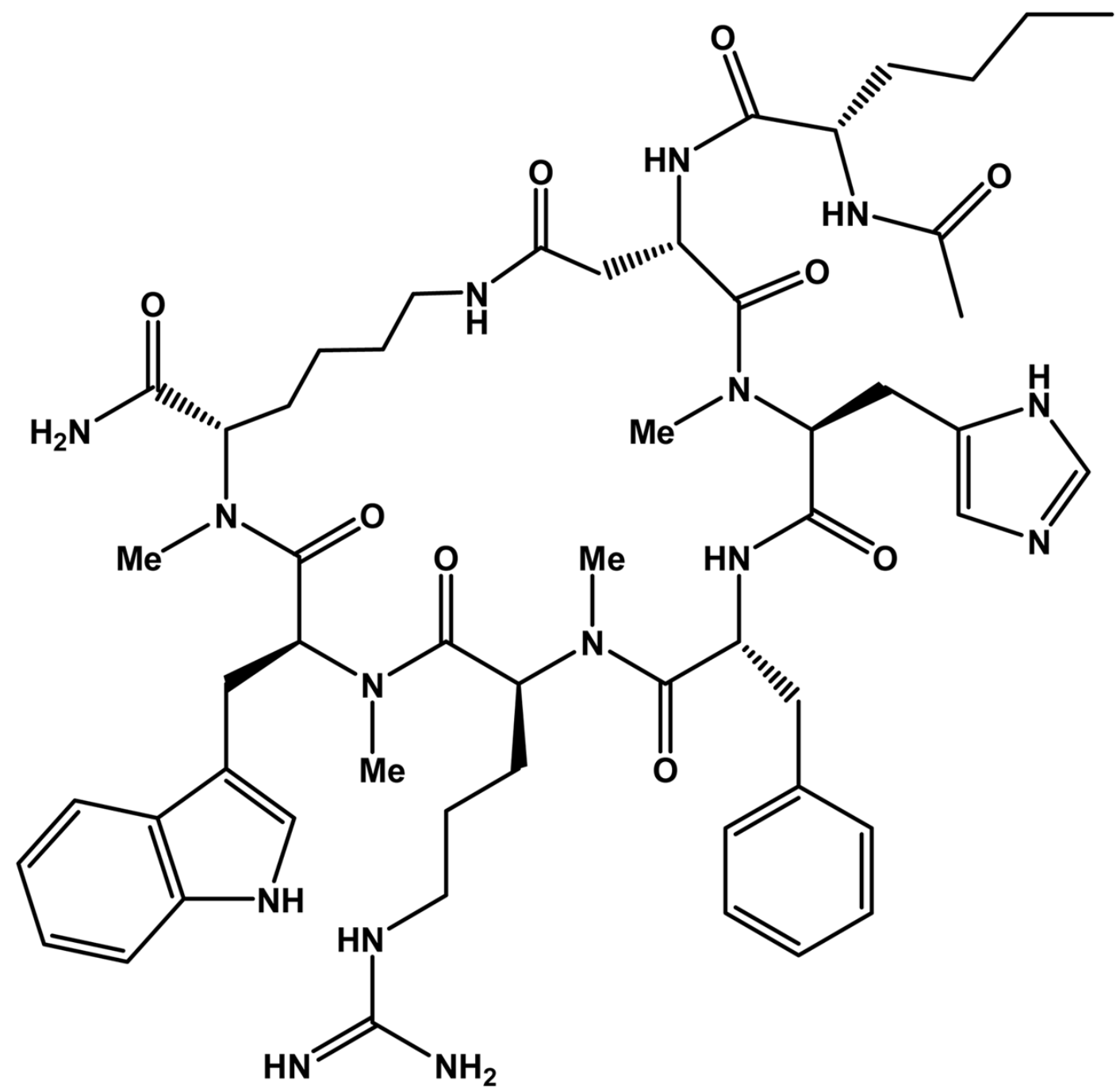

Figure 2.

Molecular structure of compound 28 


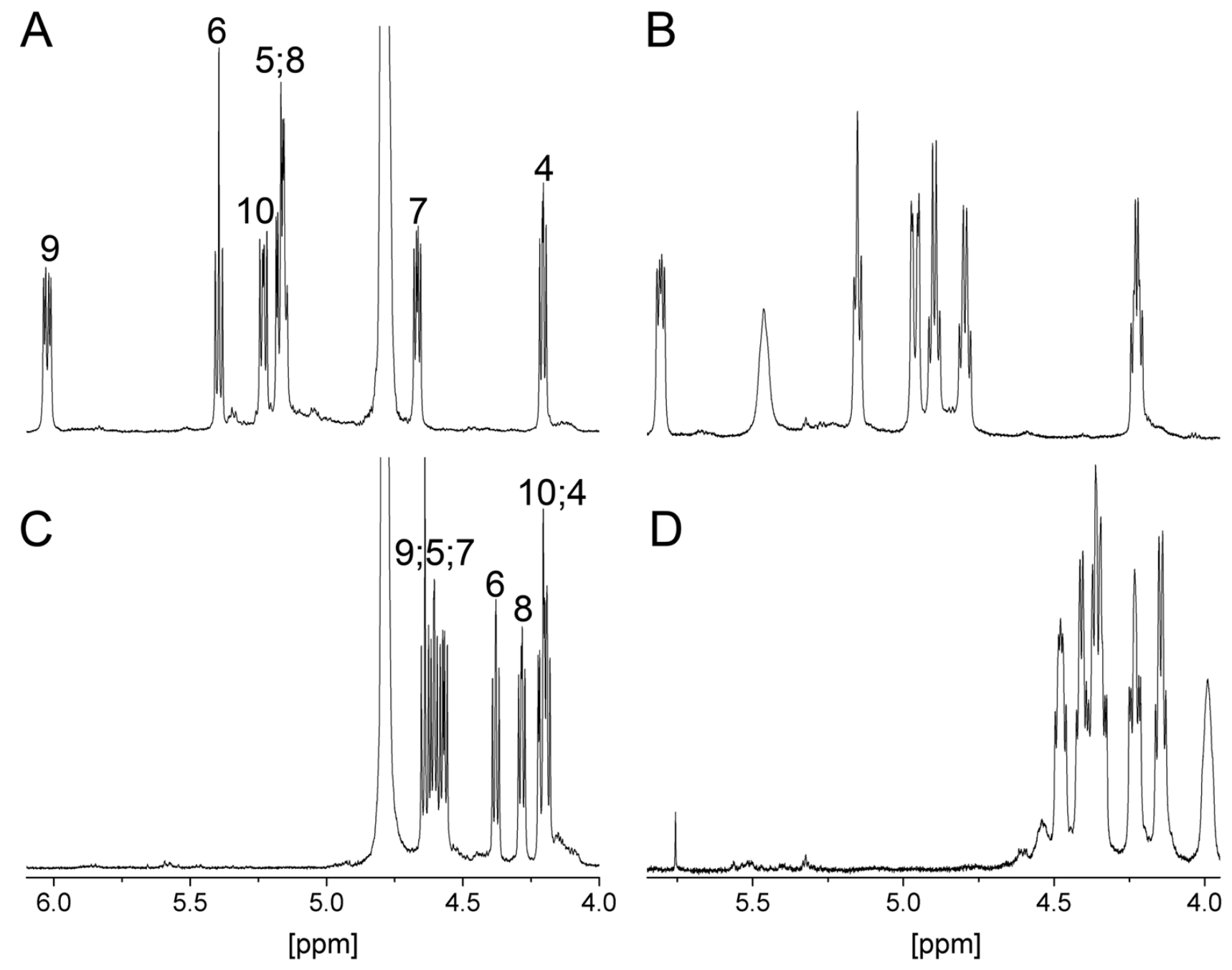

Figure 3.

$\mathrm{H}^{\alpha}$ regions of $1 \mathrm{H}$ NMR spectra of peptide 28 (A and B) and MT-II (C and D). Spectra A and $\mathrm{C}$ were detected in $50 \mathrm{mM}$ sodium acetate- $\mathrm{d}_{4} \mathrm{D}_{2} \mathrm{O}$ buffer $(\mathrm{pH} 4.5)$, B and D were detected in DMSO- $\mathrm{d}_{6}$. Numbers refer to $\mathrm{H}^{\alpha}$ atoms of the respective residues in the a-MSH sequence. 

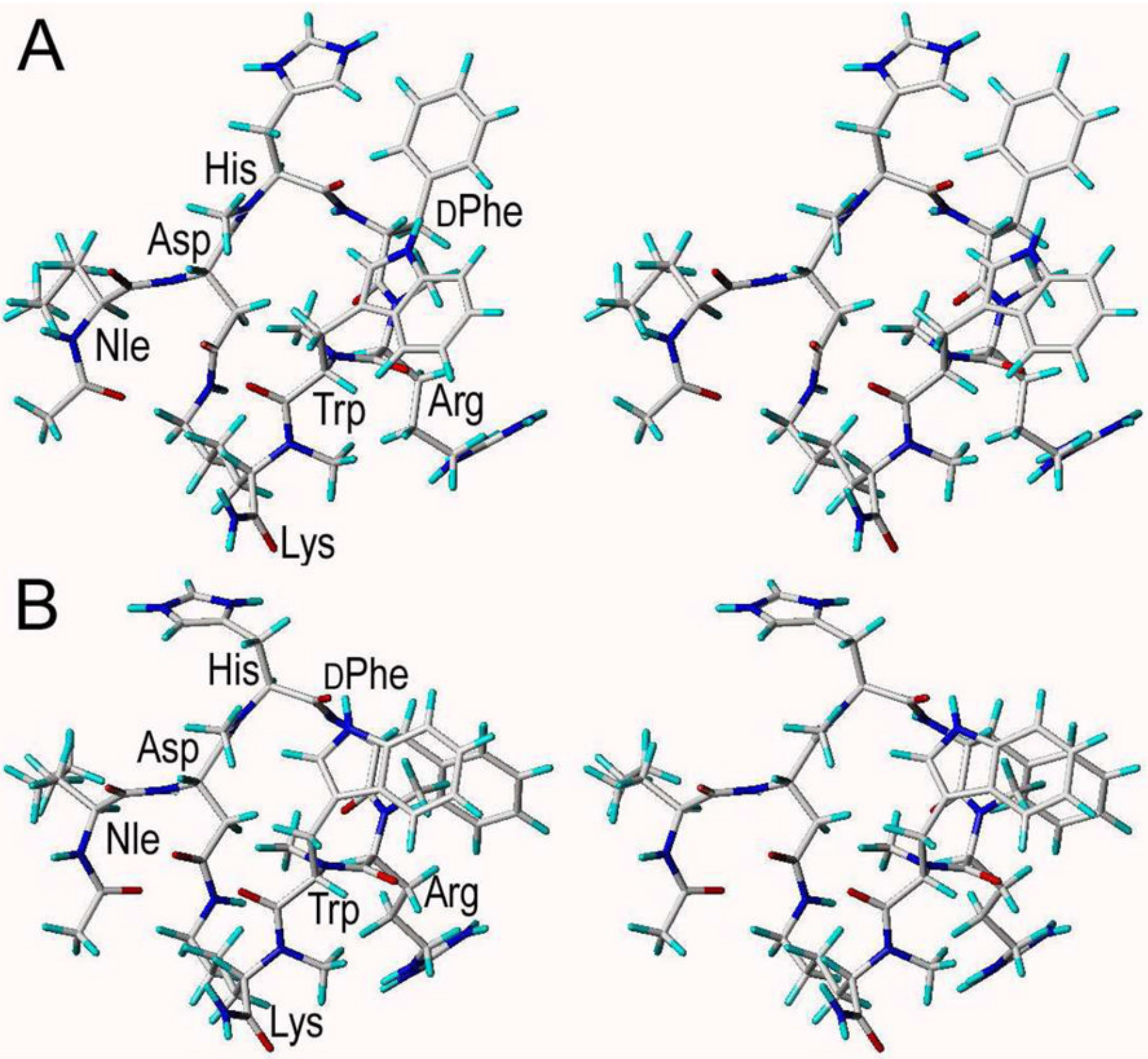

Figure 4.

Stereoviews of the solution structure of peptide $\mathbf{2 8}$ as determined by NMR spectroscopy and MD calculations. The conformers shown in $\mathbf{A}$ and $\mathbf{B}$ possess the same cyclic core structure. The different side chain conformations of $N \mathrm{Me}-\mathrm{His}^{6}, \mathrm{DPhe}^{7}$, and $\mathrm{NMe}-\mathrm{Arg}^{8}$ in $\mathbf{A}$ and $\mathbf{B}$, respectively, reflect dynamics in $\chi$ dihedral angles observed within the MD. 


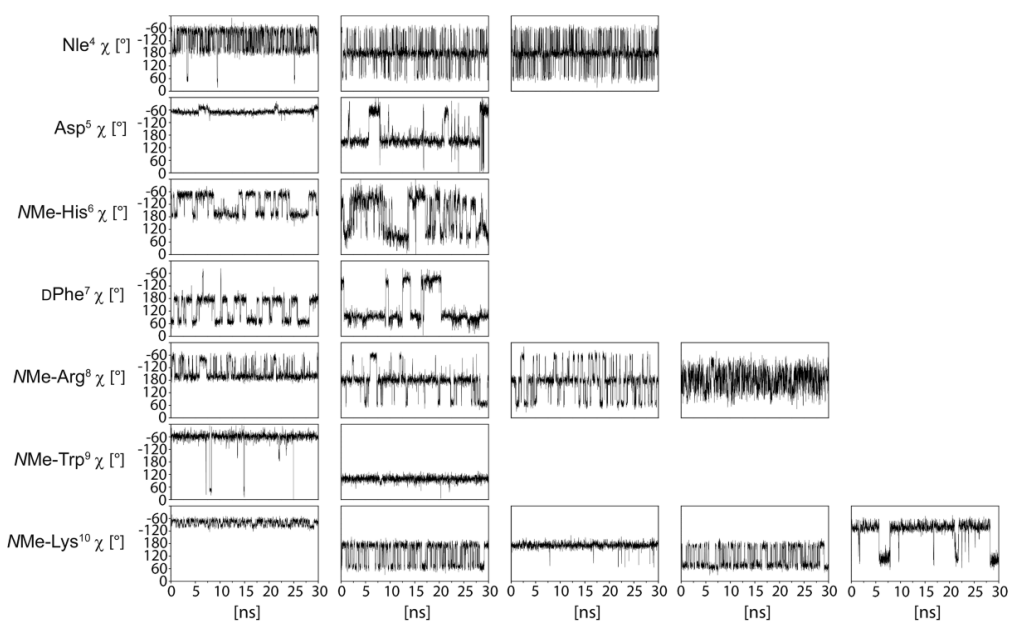

Figure 5.

$\chi$ dihedral angles as observed during the unrestrained $30 \mathrm{~ns}$ MD simulation. The column number (from the left to the right) corresponds to the $\chi$ dihedral angle positions within the sidechains. 
Table 1

Binding Assay of $N$-Methylated MT-II Analogues at hMCRs

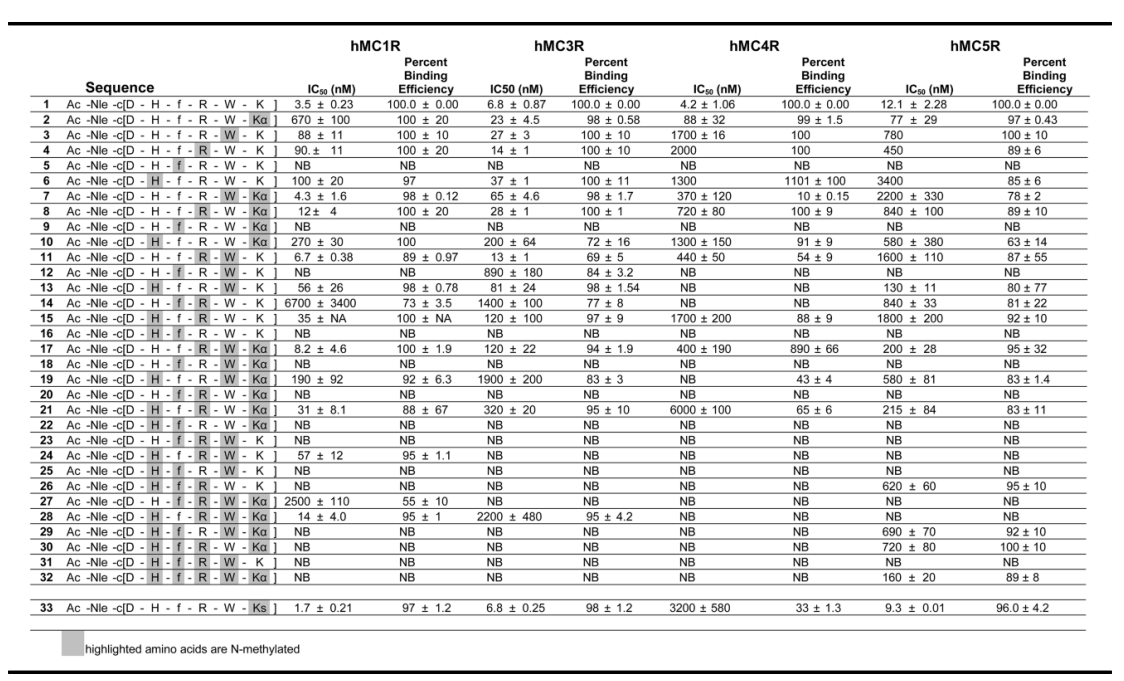

IC $50=$ concentration of peptide at $50 \%$ specific binding $(N=4)$. NB $=0 \%$ of 125 I-NDP- $\alpha-M S H$ displacement observed at $10 \mu \mathrm{M}$. Percent Binding Efficiency $=$ maximal $\%$ of ${ }^{125}$ I-NDP- $\alpha$-MSH displacement observed at $10 \mu \mathrm{M}$. 
Table 2

cAMP Assay of $N$-Methylated MT-II Analogues at hMCRs

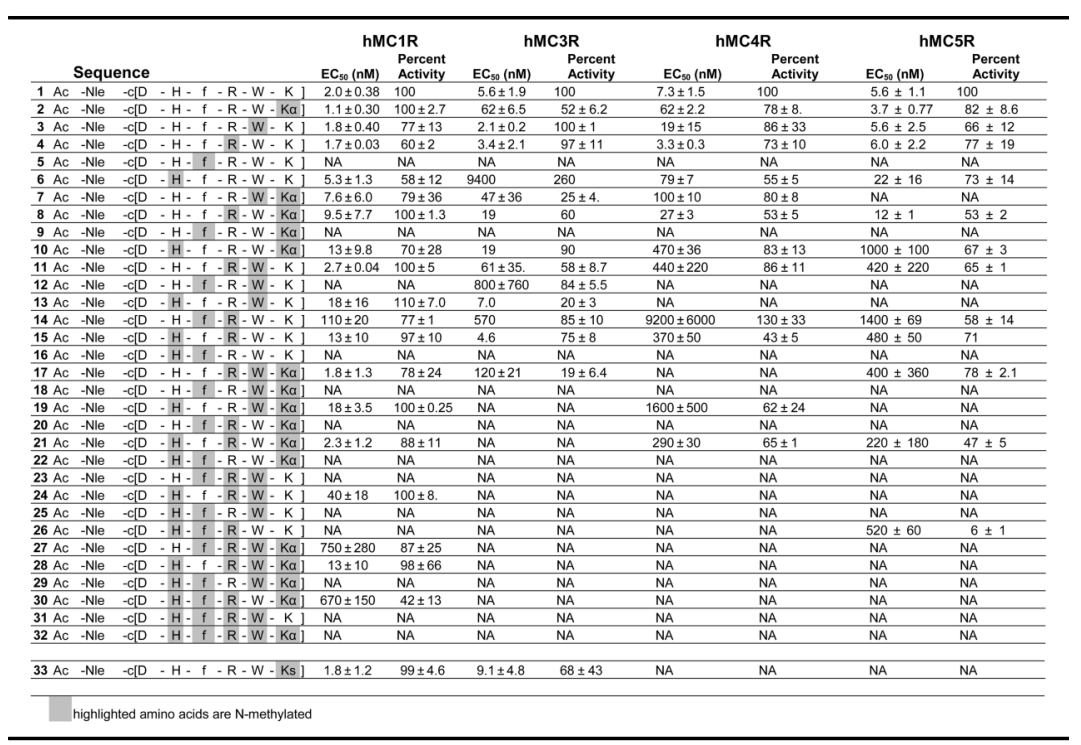

EC50 $=$ Effective concentration of peptide that was able to generate 50\% maximal intracellular cAMP accumulation $(\mathrm{N}=4)$. Percent Activity $=\%$ of cAMP produced at $10 \mu \mathrm{M}$ ligand concentration, in relation to MT-II. NA $=0 \% \mathrm{cAMP}$ accumulation observed at $10 \mu \mathrm{M}$. The peptides were tested at a range of concentration from $10^{-10}$ to $10^{-5} \mathrm{M}$. 


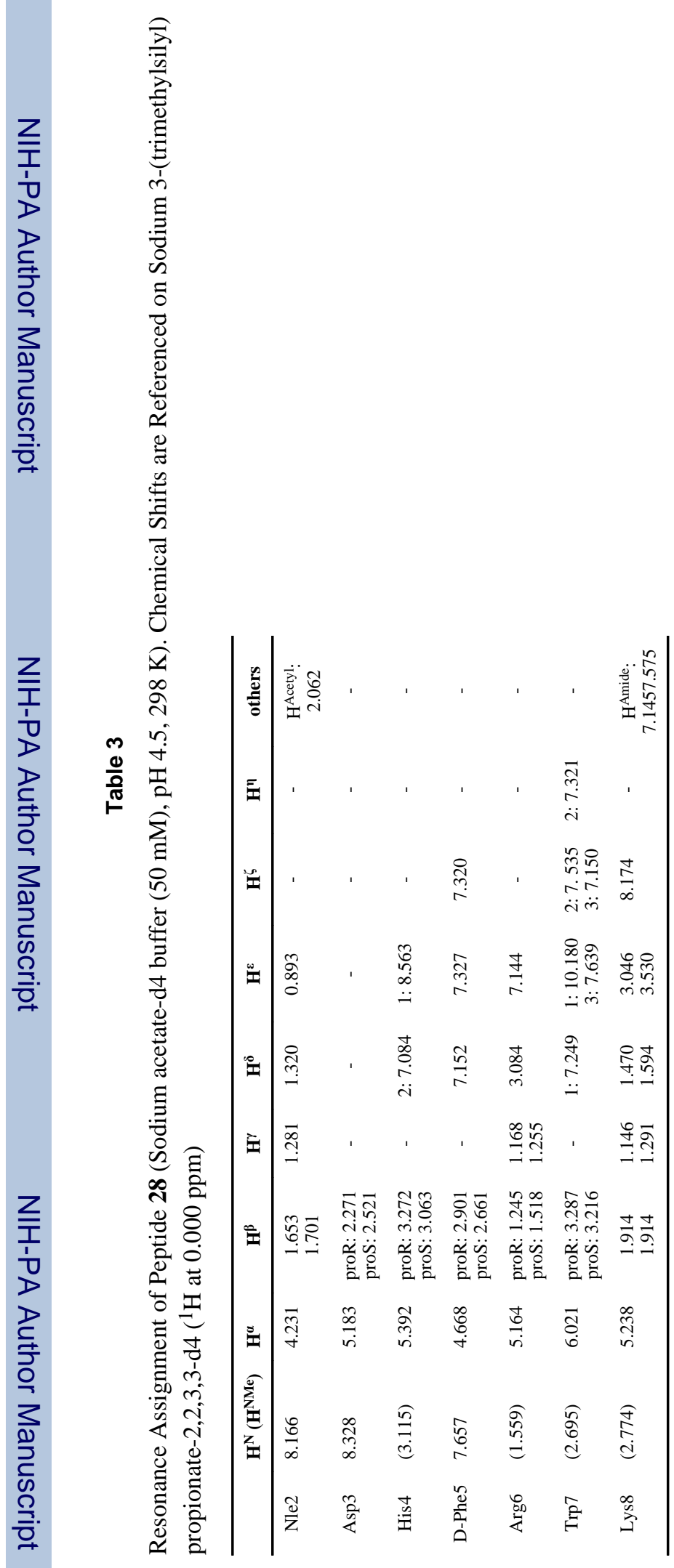




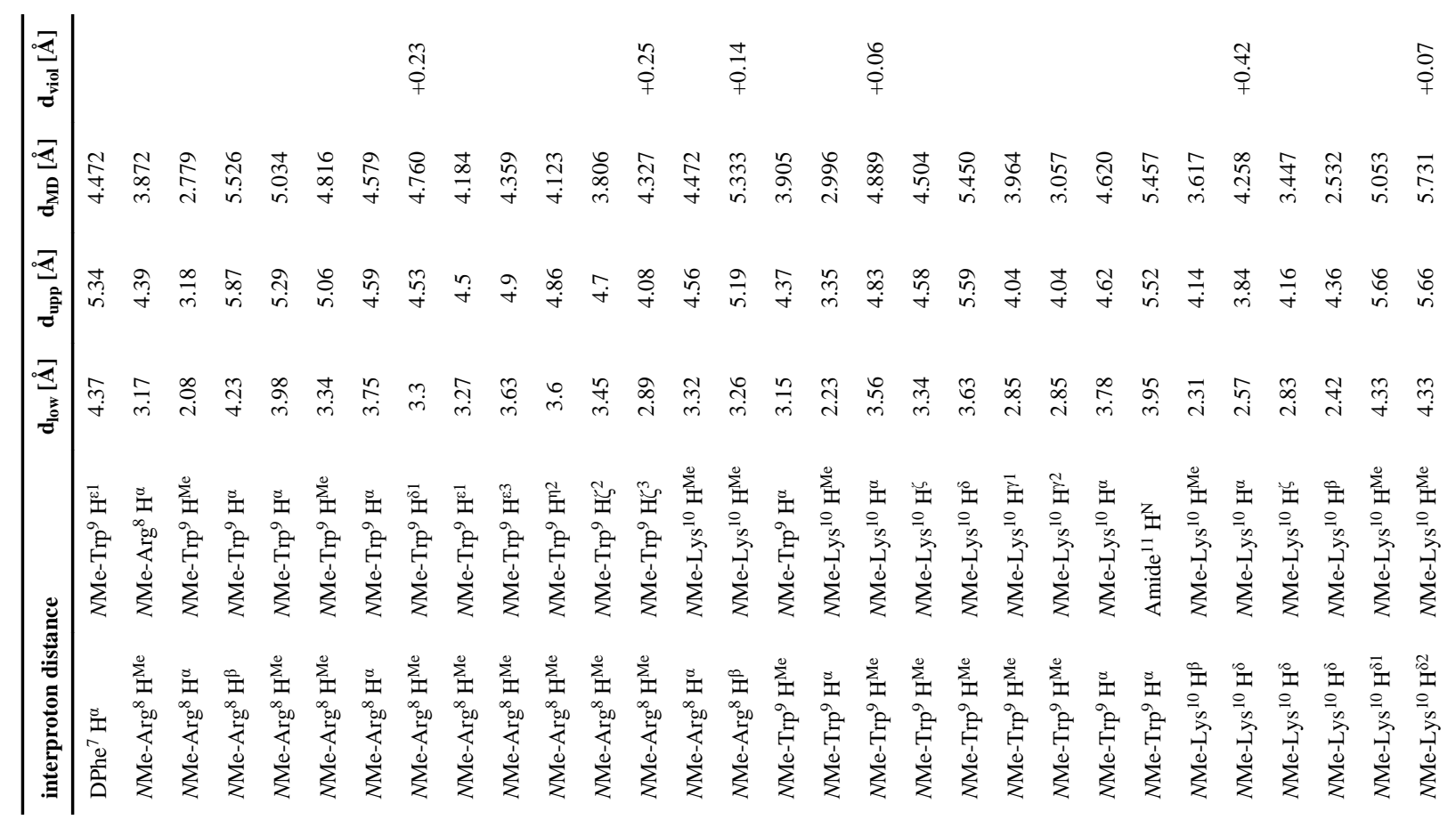




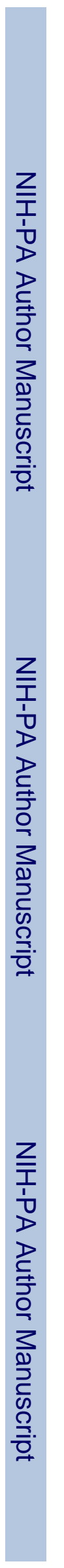

Doedens et al.

Page 29

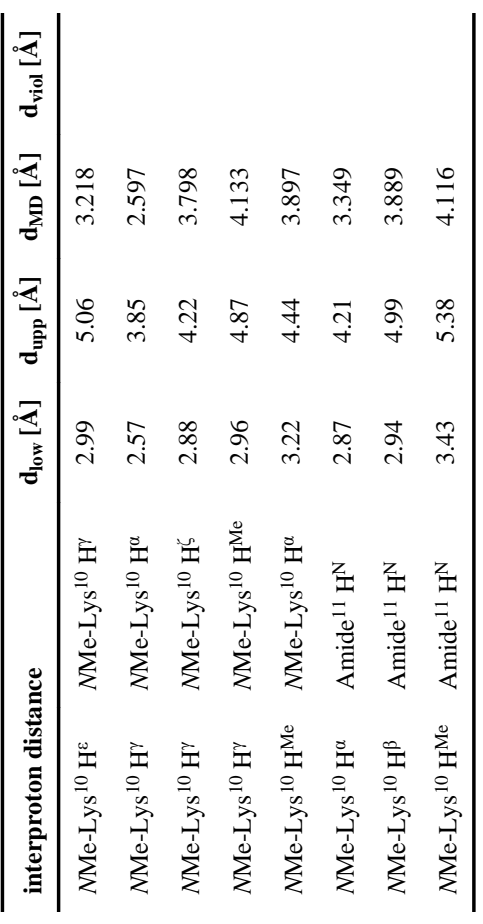

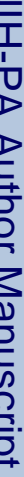

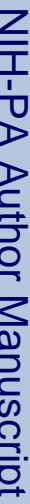

J Am Chem Soc. Author manuscript; available in PMC 2011 June 16. 


\section{Table 5}

$\Phi$ and $\Psi$ Dihedral Angles of the Average Structure from the Restrained MD (rMD) and from the Trajectory of the Unrestrained MD (MD)

\begin{tabular}{|c|c|c|c|c|}
\hline Amino acid residue & $\boldsymbol{\Phi}_{\mathrm{rMD}}\left[^{\circ}\right]$ & $\boldsymbol{\Phi}_{\mathrm{MD}}\left[^{\circ}\right]$ & $\boldsymbol{\Psi}_{\mathrm{rMD}}\left[^{\circ}\right]$ & $\boldsymbol{\Psi}_{\mathbf{M D}}\left[^{\circ}\right]$ \\
\hline $\mathrm{Nle}^{4}$ & -101 & $-75.5+/-39.6$ & 109 & $29.4+/-82.5$ \\
\hline $\mathrm{Asp}^{5}$ & 71 & $-89.7+/-32.7$ & 144 & $112.7+/-16.9$ \\
\hline$N \mathrm{Me}-\mathrm{His}^{6}$ & -98 & $-102.4+/-15.7$ & 78 & $117.4+/-19.2$ \\
\hline DPhe $^{7}$ & 96 & $75.0+/-18.8$ & -126 & $-116.0+/-10.1$ \\
\hline$N \mathrm{Me}-\operatorname{Arg}^{8}$ & -135 & $-122.9+/-8.0$ & 80 & $83.2+/-9.9$ \\
\hline$N \mathrm{Me}-\operatorname{Trp}^{9}$ & -120 & $-136.6+/-14.0$ & 63 & $96.0+/-12.7$ \\
\hline$N \mathrm{Me}-\mathrm{Lys}^{10}$ & -114 & $-120.7+/-9.9$ & 0 & $83.0+/-63.4$ \\
\hline
\end{tabular}




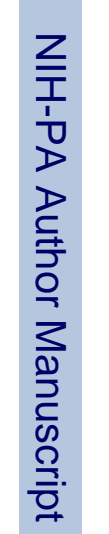

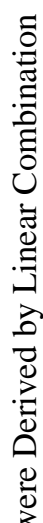

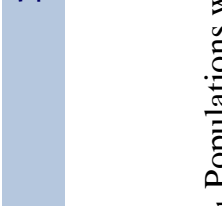

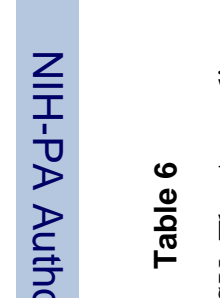

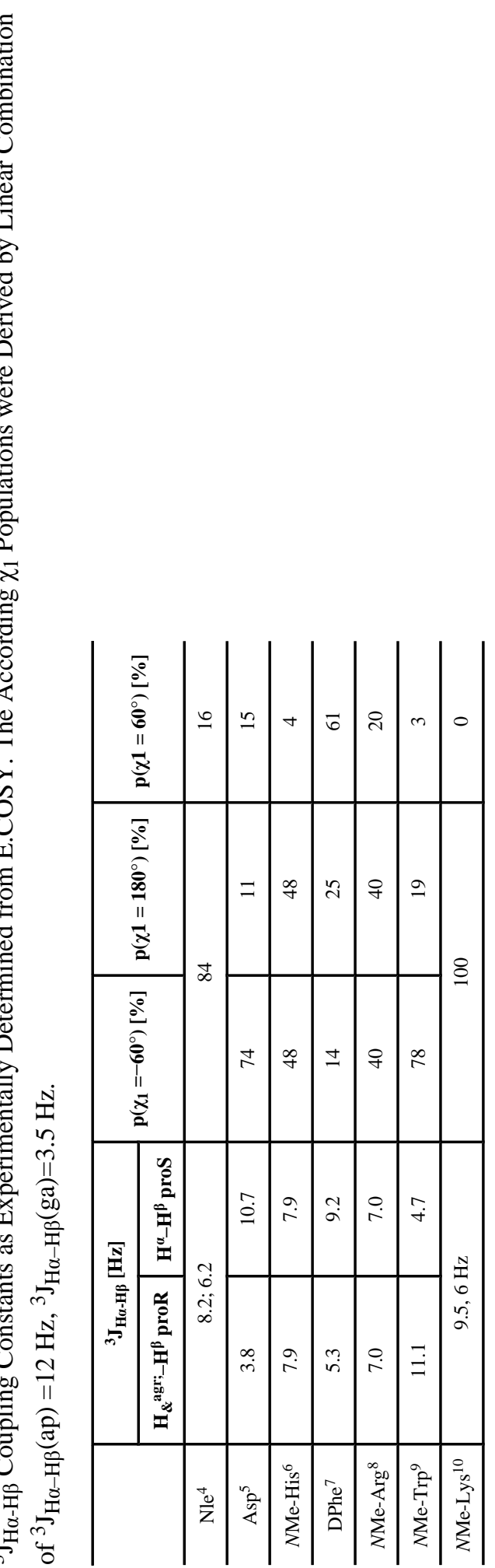

